\title{
The role of antigen presenting cells in the induction of HIV-1 latency in resting CD4 ${ }^{+}$ T-cells
}

\author{
Nitasha A. Kumar 1,2,5, Karey Cheong 1,2,5, David R. Powell ${ }^{3,4}$, Candida da Fonseca Pereira², Jenny Anderson 1,2,5, \\ Vanessa A. Evans $s^{1,2,5}$, Sharon R. Lewin ${ }^{1,2,5}$ and Paul U. Cameron 1,2,5*
}

\begin{abstract}
Background: Combination antiretroviral therapy (CART) is able to control HIV-1 viral replication, however long-lived latent infection in resting memory $\mathrm{CD}^{+}{ }^{+} \mathrm{T}$-cells persist. The mechanisms for establishment and maintenance of latent infection in resting memory $\mathrm{CD}_{4}^{+} \mathrm{T}$-cells remain unclear. Previously we have shown that HIV-1 infection of resting $\mathrm{CD}^{+}{ }^{+}$-cells co-cultured with $\mathrm{CD} 11 \mathrm{c}^{+}$myeloid dendritic cells $(\mathrm{mDC})$ produced a population of non-proliferating T-cells with latent infection. Here we asked whether different antigen presenting cells (APC), including subpopulations of DC and monocytes, were able to induce post-integration latent infection in resting $\mathrm{CD}^{+}{ }^{+} \mathrm{T}$-cells, and examined potential cell interactions that may be involved using RNA-seq.

Results: $\mathrm{mDC}\left(\mathrm{CD} 1 \mathrm{c}^{+}\right), \mathrm{SLAN}^{+} \mathrm{DC}$ and $\mathrm{CD} 14^{+}$monocytes were most efficient in stimulating proliferation of $\mathrm{CD}^{+}$ T-cells during syngeneic culture and in generating post-integration latent infection in non-proliferating $\mathrm{CD}^{+}{ }^{+} \mathrm{T}$-cells following HIV-1 infection of APC-T cell co-cultures. In comparison, plasmacytoid DC (pDC) and B-cells did not induce latent infection in APC-T-cell co-cultures. We compared the RNA expression profiles of APC subpopulations that could and could not induce latency in non-proliferating $\mathrm{CD}^{+}{ }^{+} \mathrm{T}$-cells. Gene expression analysis, comparing the $\mathrm{CD} 1 \mathrm{c}^{+}$ mDC, SLAN ${ }^{+} \mathrm{DC}$ and $\mathrm{CD} 14^{+}$monocyte subpopulations to $\mathrm{pDC}$ identified 53 upregulated genes that encode proteins expressed on the plasma membrane that could signal to $\mathrm{CD}^{+}{ }^{+}$-cells via cell-cell interactions (32 genes), immune checkpoints (IC) (5 genes), T-cell activation (9 genes), regulation of apoptosis (5 genes), antigen presentation (1 gene) and through unknown ligands (1 gene).
\end{abstract}

Conclusions: APC subpopulations from the myeloid lineage, specifically mDC subpopulations and $\mathrm{CD}_{14^{+}}$monocytes, were able to efficiently induce post-integration HIV-1 latency in non-proliferating CD4 ${ }^{+}$T-cells in vitro. Inhibition of key pathways involved in mDC-T-cell interactions and HIV-1 latency may provide novel targets to eliminate HIV-1 latency.

Keywords: Dendritic cells, Monocytes, B-cells, HIV Latency, Resting CD4 ${ }^{+}$T-cells, Antigen presenting cells, APC, Viral reservoir, Latency induction, Post-integration latency

\section{Background}

Despite the successes of cART in the reduction of morbidity and mortality world wide, treatment is required life long. HIV-1 persists in individuals on cART in resting $\mathrm{CD} 4^{+} \mathrm{T}$-cells as latent infection [1-3]. Latency occurs

\footnotetext{
*Correspondence: paul.cameron@unimelb.edu.au

${ }^{5}$ Doherty Institute for Infection and Immunity, University of Melbourne,

Melbourne 3010, Australia

Full list of author information is available at the end of the article
}

when viral DNA is integrated within the host genome and remains transcriptionally silent. Latent infection of resting $\mathrm{CD}_{4}^{+} \mathrm{T}$-cells therefore represents the major barrier to HIV-1.

It remains unclear how latency is established in resting $\mathrm{CD} 4^{+} \mathrm{T}$-cells in vivo. Initial studies in vitro, showed that direct HIV-1 infection of resting $\mathrm{CD} 4^{+}$T-cells isolated from peripheral blood was inefficient and integration rarely occurred due to incomplete reverse transcription, 
reduced nuclear import of the viral DNA and/or limited integration within the host genome [4-6]. However, in vitro latent infection can occur following the reversion of a HIV-1 infected, activated CD4 ${ }^{+}$T-cell to a resting state [7-10]. Alternatively, latent infection can also occur following the direct infection of a resting $\mathrm{CD} 4^{+} \mathrm{T}$-cell exposed to high viral titers and spinoculation [11, 12], chemokines [13] or co-culture with other cell types [14, 15].

As professional APCs, DC interact with HIV-1 during initial infection at vaginal and rectal mucosa sites and in blood. Langerhan cells (LC) and dermal (D)DC at mucosa and, bone marrow derived classical or myeloid (m)DC and plasmacytoid (p)DC in blood are able to interact with T-cells, but their role in the establishment and maintenance of HIV-1 latency remain unclear [16-18]. Blood derived $\mathrm{mDC}$ subpopulations differ from tissue DC. CD141 ${ }^{+}$and $\mathrm{CD} 1 \mathrm{c}^{+} \mathrm{mDC}$ are both found as resident cells in tissue (lymph node (LN), spleen, lungs), skin and, as more mature cells, circulating through the lymphatics to the LN [19-22]. SLAN ${ }^{+}$DC represent a subpopulation of monocytic cells with increased potential to secrete pro-inflammatory cytokines and develop a DC phenotype, however precise residence remains unknown [23, 24]. CD14 $4^{+}$monocytes represent DC and macrophage precursors in blood [Reviewed in 25], and were also tested for their ability to establish latent infection in resting $\mathrm{CD} 4^{+} \mathrm{T}$-cells.

We have previously developed an in vitro co-culture model demonstrating that $\mathrm{CD} 11 \mathrm{c}^{+}$myeloid dendritic cells $(\mathrm{mDC})$ induce post-integration latency in non-proliferating memory $\mathrm{CD} 4^{+}$T-cells. Here we demonstrate that in addition to the $\mathrm{mDC}$ subsets $\left(\mathrm{CD} 1 \mathrm{c}^{+}, \mathrm{SLAN}^{+}\right.$ and $\left.\mathrm{CD} 141^{+}\right), \mathrm{CD} 14^{+}$monocytes were also able to induce post-integration HIV-1 latency in non-proliferating $\mathrm{CD}_{4}^{+}$T-cells. In comparison, T-cells co-cultured with pDC and B-cells were inefficient in the induction of latency. Using RNA-seq and Illumina gene expression microarrays, we also identified potential mediators of latent infection expressed by APC that could induce latency in the non-proliferating $\mathrm{CD}^{+}{ }^{+} \mathrm{T}$-cells during APC-T cell interactions.

\section{Results}

\section{Monocytes are able to induce latency in resting $\mathrm{CD}^{+}$ T-cells}

We have previously reported that $\mathrm{mDC}$, but not $\mathrm{pDC}$, are able to efficiently induce post-integration latent infection in resting $\mathrm{CD} 4^{+} \mathrm{T}$-cells using an in vitro $\mathrm{DC}$ T-cell co-culture model [14]. However, $\mathrm{mDC}$ and their subpopulations represent only a small proportion of peripheral blood mononuclear cells (PBMC) compared to monocytes, which represent a precursor to some DC and macrophage subpopulations. Therefore we compared monocytes and $\mathrm{mDC}$ isolated from healthy donors for their ability to induce latent infection in resting $\mathrm{CD} 4^{+}$ T-cells (Fig. 1). efluor670 labeled resting $\mathrm{CD} 4^{+}$T-cells were cultured alone, with $\mathrm{CD} 11 \mathrm{c}^{+} \mathrm{mDC}$ or bulk monocytes and infected with an R5 using virus that expresses enhanced green fluorescent protein (EGFP). Similar to $\mathrm{mDC}$, monocytes were able to induce productive infection in $\mathrm{CD} 4^{+} \mathrm{T}$-cells, as measured by total EGFP expression at day 5 post-infection (Fig. 1b). At day 5 postinfection non-proliferating (eFluor670 ${ }^{\text {hi }} \mathrm{EGFP}^{-}$) CD4 ${ }^{+}$ T-cells were sorted and cultured with phytohemagglutinin (PHA)-stimulated feeder peripheral blood mononuclear cells (PBMC), where the number of $\mathrm{EGFP}^{+}$cells was quantified by flow cytometry as a surrogate marker of inducible latent infection. $\mathrm{CD} 14^{+}$monocytes were also able to significantly increase the induction of latent infection in non-proliferating cells ( $\mathrm{p}>0.05$; Fig. 1c).

\section{Isolation of functional APC}

Given that we were able to show induction of latency in non-proliferating $\mathrm{CD} 4^{+} \mathrm{T}$-cells following co-culture with both bulk monocytes and $\mathrm{mDC}$, we next compared the latency inducing potential of the different monocyte and $\mathrm{mDC}$ subpopulations. Monocytes were sorted into $\mathrm{CD}_{1} 4^{+}$and $\mathrm{CD} 14^{\mathrm{lo}} \mathrm{CD} 16^{+}\left(\mathrm{CD} 16^{+}\right)$cells and $\mathrm{mDC}$ were sorted into $\mathrm{CD} 1 \mathrm{c}^{+}, \mathrm{CD} 141^{+}$and $\mathrm{SLAN}^{+} \mathrm{DC}$, B-cells and pDC were also isolated by sorting (Fig. 2a). The final purity for all sorted APC subpopulations was $>90 \%$, as determined post-sort by expression of specific known surface markers for the various subpopulations [26-30]. The APC subpopulations were examined using brightfield microscopy after culture (Fig. 2b, c). The mDC and monocyte subpopulations were characterized with the formation of both long and short dendritic processes (Fig. 2b, c) Comparatively, pDC and B-cells had few processes or ruffles (Fig. 2b, c; [28, 29, 31-33]).

APC function was tested in a syngeneic mixed leukocyte reaction (MLR) using the proliferation dye eFluor670 to measure proliferation of resting $\mathrm{CD} 4^{+} \mathrm{T}$-cells. In the absence of mitogen stimulation, the relative potency of the various $\mathrm{APC}$ to induce $\mathrm{T}$-cell proliferation at a ratio of 1 APC:10 CD4 ${ }^{+}$T-cells is shown (Fig. 3a). CD1c ${ }^{+}$DC were the most potent at activating resting $\mathrm{CD} 4^{+} \mathrm{T}$-cells, while $\mathrm{pDC}$ and $\mathrm{CD} 141^{+} \mathrm{DC}$ were least potent. The use of superantigen staphylococcal enterotoxin B (SEB) at low dose in the MLR had a modest effect on enhancing the capacity of APC to induce T-cell proliferation. T-cell proliferation following co-culture and SEB treatment was highest with $\mathrm{CD}_{1} \mathrm{c}^{+} \mathrm{DC}$ and lowest with B-cells (Fig. 3b), confirming previous observations by others [26]. B-cells had a similar stimulatory capacity with and without superantigen (1.0 and $1.3 \%$ proliferated $\mathrm{CD} 4^{+} \mathrm{T}$-cells). 

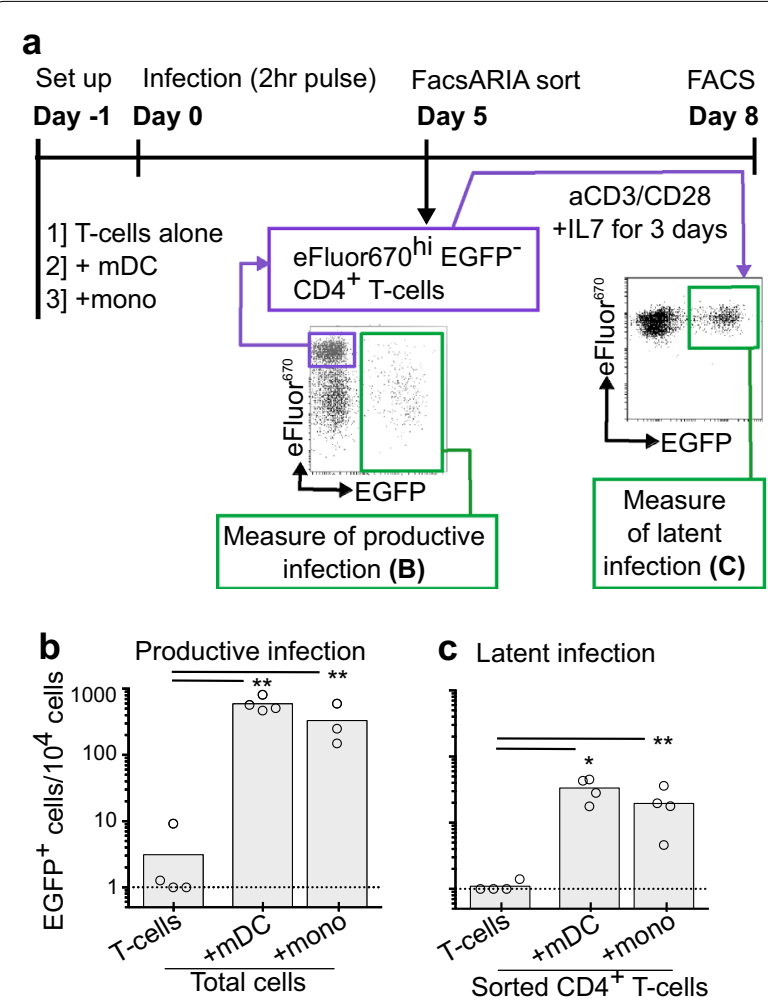

Fig. 1 Monocyte induced latency in non-proliferating $C D 4^{+} \mathrm{T}$-cells. a Resting CD4 ${ }^{+}$T-cells were labeled with eFluor670 and cultured alone, with bulk myeloid (m)DC or bulk monocytes (mono) at a ratio of 10:1. Following 24 h of culture, APC-T-cell co-cultures were infected with $\mathrm{NL}(\mathrm{AD} 8) \Delta$ nef-EGFP. $\mathbf{b}$ At day 5 post-infection productive infection was determined by quantification of EGFP in total cells and, nonproliferating, non-productively infected (eFluor670 ${ }^{\text {hi }}$ GFP $^{-}$) cells were sorted using flow cytometry and reactivated to determine frequency of latent infection. c Sorted non-proliferating (eFluor670 ${ }^{\text {hi }}$ GFP $^{-}$) $\mathrm{CD}^{+}{ }^{+}$T-cells were stimulated with phytohaemagglutinin (PHA) stimulated feeder PBMC for 5 days and EGFP quantified as a measure of HIV-1 latency. Columns represent the median of the log transformed values, open circles represent individual donors. ${ }^{*} p \leq 0.05,{ }^{* *} p \leq 0.005$ as determined by paired students t-test

Finally, there was a dose response of $\mathrm{CD} 4^{+} \mathrm{T}$-cell proliferation with decreasing APC:T-cell ratio (1:10-1000). Together, these data confirm that all the APC subpopulations isolated remained functional in the co-cultures used for infection.

\section{T-cell stimulation by APC subpopulations in HIV-1 infected co-cultures}

We then measured T-cell proliferation following coculture with different APC subpopulations at 3 days following HIV-1 infection. The pattern of APC potency in induction of $\mathrm{CD}_{4}^{+} \mathrm{T}$-cell proliferation in the presence of HIV-1 was similar to uninfected, sygeneic, co-cultures (Fig. 3c), where proliferation of $\mathrm{CD}^{+} \mathrm{T}$-cells was highest with $\mathrm{CD}_{1} \mathrm{c}^{+} \mathrm{DC}$ and lowest with $\mathrm{pDC}$. These experiments demonstrate that HIV-1 infection did not independently alter APC or T-cell function with respect to T-cell proliferation.

\section{Several APC subpopulations enhanced productive infection of resting $\mathrm{CD}^{+}{ }^{+} \mathrm{T}$-cells}

We tested the ability of APC subpopulations to induce both productive and latent infection in resting $\mathrm{CD}_{4}^{+}$ T-cells when cultured alone or co-cultured with one of the seven sorted APC subpopulations (Fig. 2a). Five days following infection, EGFP expression was quantified by flow cytometry as a measure of productive infection (Fig. 4a). We observed a significant increase in productive infection following HIV-1 infection in all APC cocultured with $\mathrm{T}$-cells compared to resting CD4 ${ }^{+} \mathrm{T}$-cells cultured alone ( $\mathrm{p}=0.03$ for all APC co-cultures; Fig. $4 \mathrm{~b}$ ).

\section{Different APC subpopulations can effectively induce latent infection in non-proliferating $\mathrm{CD}^{+}{ }^{+} \mathrm{T}$-cells}

Five days following infection, non-proliferating (eFluor670 ${ }^{\text {hi }} \mathrm{EGFP}^{-}$) CD4 ${ }^{+}$T-cells were sorted from the APC-T-cell co-cultures to quantify latent infection (Fig. 4a). The sorted CD4 ${ }^{+}$T-cells were directly stimulated with anti-CD3/CD28 and IL-7 (Fig. 4c) in the presence and absence of an integrase inhibitor, L8. EGFP was quantified by flow cytometry as a measure of inducible latent infection. Total latent infection (no L8) was significantly increased in non-proliferating $\mathrm{CD} 4^{+}$T-cells co-cultured with all $\mathrm{mDC}$ subpopulations, $\mathrm{CD} 14^{+}$monocytes and B-cells, when compared to $\mathrm{CD} 4^{+}$T-cells cultured alone $(p=0.03$; Fig. $4 d)$. In comparison, total latent infection following co-culture with $\mathrm{CD} 14^{\mathrm{lo}} \mathrm{CD} 16^{+}$ monocytes, that were depleted of $\mathrm{SLAN}^{+} \mathrm{DC}$, was highly variable and not significantly different to T-cells cultured alone. As previously shown, latent infection was not found in T-cells co-cultured with $\mathrm{pDC}(\mathrm{p}=0.03$ compared to mDC co-cultures; Fig. 4d).

We also quantified post-integration latent infection by stimulating T-cells with anti CD3/CD28 and IL-7 stimulation in the presence of L8. (Fig. 4c). The integrase inhibitor, L8, prevented any progression of pre-integration complexes to integration and inhibited secondary rounds of infection. Following infection of $\mathrm{CD}^{+}$T-cells cocultured with each APC subpopulation, post-integration latency followed a similar pattern to that observed for total latency, but at a lower frequency (Fig. 4d, e). Postintegration latency was significantly increased in $\mathrm{CD}^{+}$ T-cells following co-culture with $\mathrm{mDC}$ subpopulations $\mathrm{CD}_{1}{ }^{+}$and $\mathrm{SLAN}^{+}$, and CD14 ${ }^{+}$monocytes $(\mathrm{p}=0.03$, 0.02 and 0.01 , respectively; Fig. 4e). Post-integration latency induced by $\mathrm{CD} 141^{+} \mathrm{DC}$ was elevated, similar to what was induced by other mDC subsets, but this did 

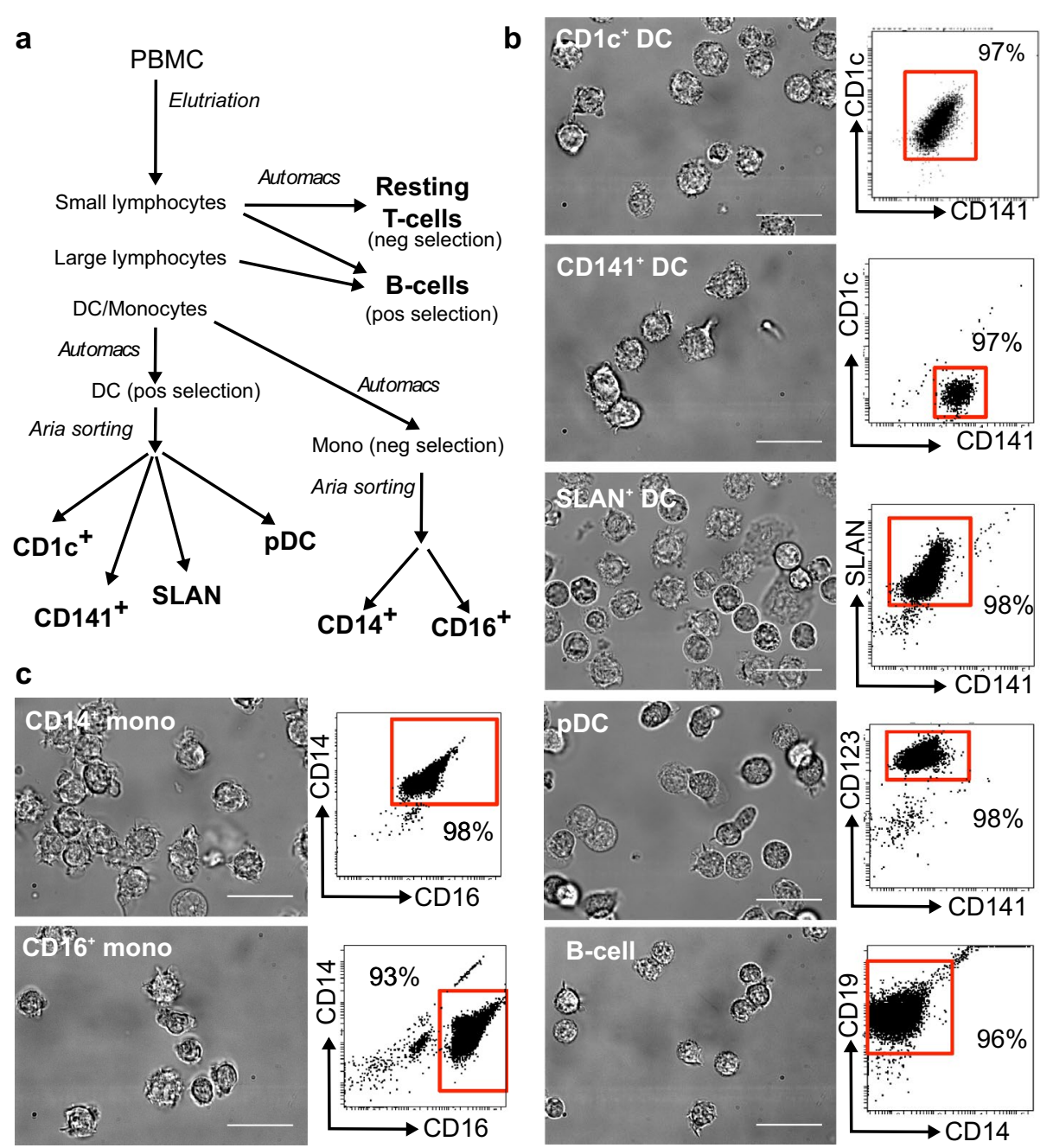

Fig. 2 Isolation of antigen presenting cells. a Peripheral blood mononuclear cells (PBMC) were elutriated into three fractions: small lymphocytes, large lymphocytes and a monocyte/DC fraction. Resting CD4 ${ }^{+}$T-cells were isolated from the small lymphocyte fraction by negative selection using magnetic beads. Bulk B-cells were isolated from a mixture of the small and large lymphocyte fractions using positive magnetic bead selection for CD19. Bulk DC subpopulations were positively selected on the basis of expression of CD1C, CD141, SLAN and CD123 from the DC/monocyte fraction using magnetic bead selection. The positive "DC enriched" (DC) population was then sorted by flow cytometry into the four DC populations (purity $>95 \%$ ). The negative "DC depleted" (mono) fraction was labeled with the monocyte markers CD14 and CD16, positively selected using magnetic beads and further sorted by flow cytometry into CD $14^{+}$and $C D 14^{l o} \mathrm{CD} 16^{\text {hi }}$ subsets (purity $>90 \%$ ). b, c Representative dot plots and brightfield images show the purity and morphology of the sorted APC subpopulations, respectively. The scale bars represent $20 \mu \mathrm{m}$, images were annotated using ImageJ software

not reach statistical significance. In comparison, HIV-1 infection of T-cells co-cultured with SLAN DC depleted $\mathrm{CD} 14^{-} \mathrm{CD} 16^{+}$monocytes, B-cells and $\mathrm{pDC}$ was similar to infection of $\mathrm{CD}_{4}^{+} \mathrm{T}$ cells alone. Together these data show that only CD1c ${ }^{+} \mathrm{mDC}$, SLAN ${ }^{+} \mathrm{DC}$ and CD14 ${ }^{+}$ monocytes were able to establish post-integration latent infection in non-proliferating $\mathrm{CD} 4^{+} \mathrm{T}$-cells, while B-cells and $\mathrm{CD} 141^{+} \mathrm{mDC}$ were able to establish pre-integration latent infection. $\mathrm{CD} 14^{\mathrm{lo}} \mathrm{CD} 16^{\mathrm{hi}} \mathrm{SLAN}^{-}$monocytes, like $\mathrm{pDC}$, were unable to establish either pre or post-integration latency.
Next, we looked for a correlation between productive infection and post-integration latency following infection of T-cells co-cultured with different APC (Fig. 4f). Overall, we found a weak correlation between productive and latent infection (Spearman's $r=0.12 ; p=0.02$ ), which supports our previous findings [14]. However, the induction of productive infection does not inevitably lead to post-integration latency in resting $\mathrm{CD} 4^{+} \mathrm{T}$-cells, as observed following co-culture with $\mathrm{CD} 14^{\mathrm{lo}} \mathrm{CD} 16^{\text {hi }}$ monocytes, B-cells and pDC. We conclude that cells able to establish both productive and latent infection likely share 


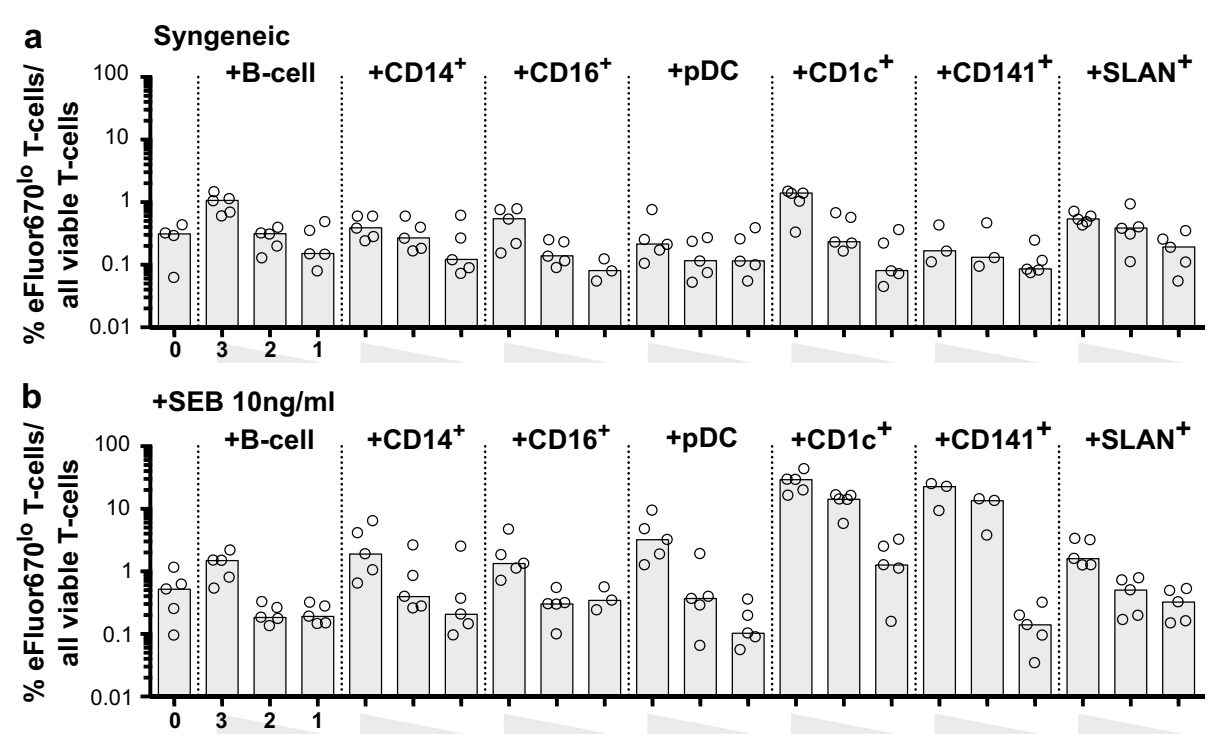

$\log _{10}$ of antigen presenting cells added to $10^{5} \mathrm{~T}$-cells

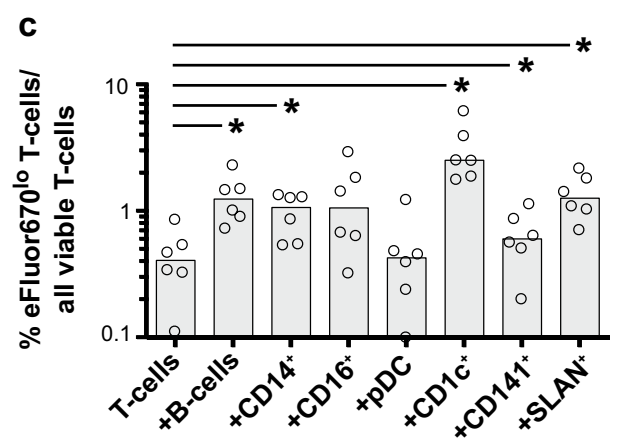

Fig. 3 Resting $\mathrm{CD}^{+}{ }^{+}$T-cell stimulation following co-culture with antigen presenting cells. Resting $\mathrm{CD} 4^{+}{ }^{-}$-cells were labeled with the proliferation dye efluor670 and co-cultured with one of seven antigen presenting cell (APC) subpopulations, including B-cells; monocyte subpopulations$\mathrm{CD} 14^{\mathrm{hi}}$ and $\mathrm{CD} 14^{\mathrm{lo}} \mathrm{CD} 16^{\mathrm{hi}} ; \mathrm{DC}$ subpopulations- plasmacytoid (p)DC and myeloid (m)DC subpopulations-CD1 $\mathrm{C}^{+}, \mathrm{CD}_{141^{+}}$and SLAN ${ }^{+}$, at a ratio of $\log 1$ (10:1), 2 (100:1) or 3 (1000:1) T-cells : APC. T-cell stimulation was measured by quantification of the percentage of eFluor670 ${ }^{\mathrm{lo}} \mathrm{CD}^{+}{ }^{+} \mathrm{T}$-cells from APC-T-cell co-cultures following 5 days of culture in the $\mathbf{a}$ absence (syngeneic) or $\mathbf{b}$ presence of staphylococcal enterotoxin B (SEB). c eFluor670 labeled, resting CD4 ${ }^{+}$T-cells were cultured alone, or with APC subpopulations at a ratio of 10:1 and infected with NL(AD8) $\Delta$ nef-EGFP. At day 3 post-infection, $\mathrm{CD}^{+}{ }^{+}$eFluor670 ${ }^{\mathrm{lo}} \mathrm{T}$-cells were measured. Columns represent the median, open circles represent individual donors, ${ }^{*} \mathrm{P} \leq 0.05$, as determined by Wilcoxon matched pairs signed rank test

common functional characteristics, which favour the establishment and maintenance of latent infection.

\section{Differential gene expression of cell-surface expressed molecules on APC}

We next used RNA-seq to compare gene expression for genes involved in T-cell interactions with APC subpopulations that induce latency $\left(C D 1 c^{+} \mathrm{DC}, \mathrm{SLAN}^{+} \mathrm{DC}\right.$ and $\mathrm{CD}_{14}{ }^{+}$monocytes) compared to APC that could not (pDC). Due to difficulties isolating APC from T-cell cocultures and HIV-1 infection, gene expression analysis was performed on freshly isolated APC subpopulations [34-36]. Component analysis showed clustering of the
SLAN DC and CD14 monocytes and separate clusters of pDC and $\mathrm{mDC}$ (Additional file 1: Figure S1). Given that we have previously shown that cell contact is important in mDC-induced latency [14], we specifically selected genes encoding proteins that mediate $\mathrm{mDC}$-T-cell interactions, including those in cell membrane compartments at the cell surface, and in intracellular vesicles such as endosomes and compartments giving rise to exosomes.

In APC subpopulations that induced post-integration HIV-1 latency compared to APC that didn't induce latency, we found 754 differentially upregulated genes (fold change $\geq 2$, p-value $<0.01$; Fig. $5 \mathrm{a}$ ). Analysis for expression in cellular compartment (GeneCodis; http:// 
a

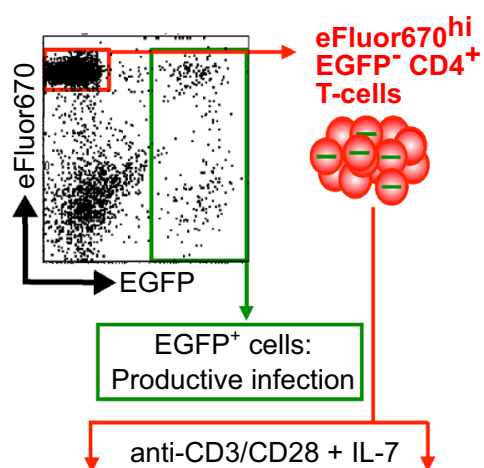

- L8

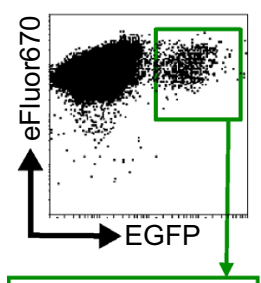

[1] Amplification of latent signal. TOTAL LATENCY

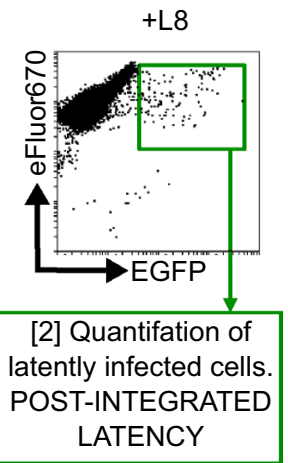

LATENCY

f Correlation of productive to latent infection

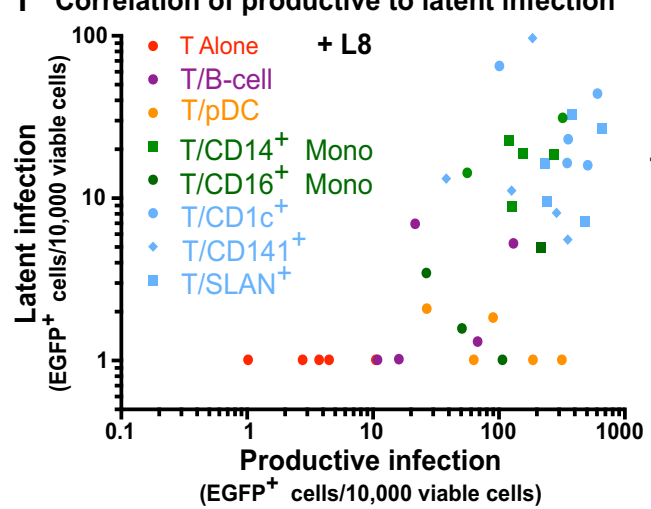

\section{b Productive Infection}

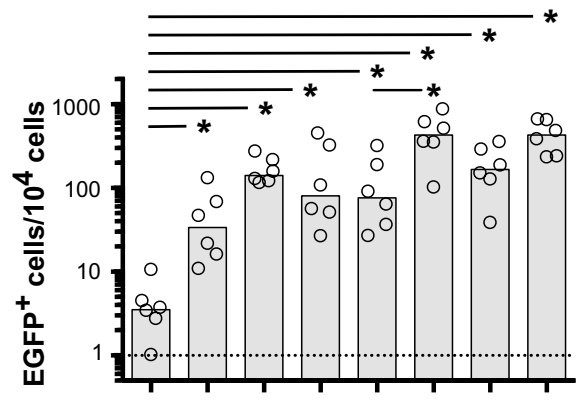

d Total Latency
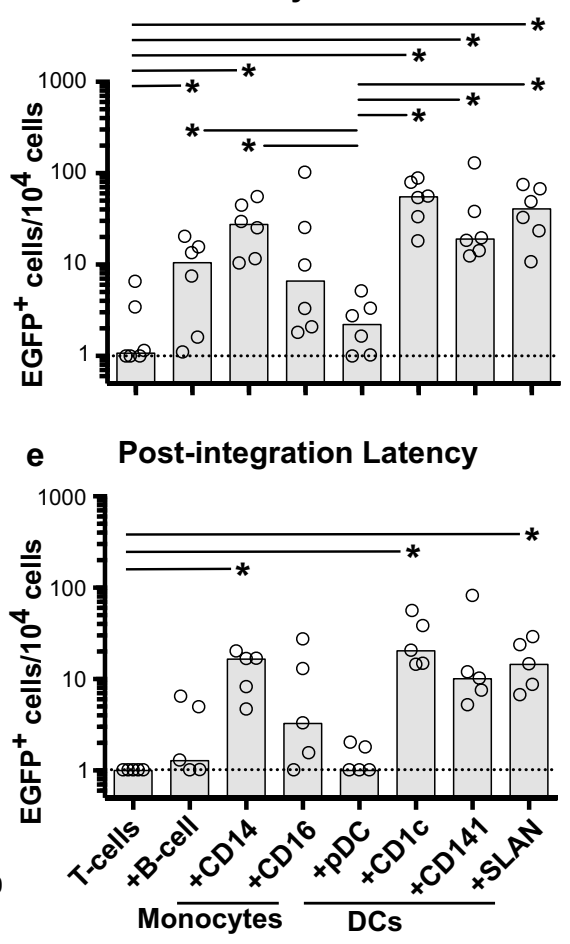

Fig. 4 Productive and latent infection in resting T-cells co-cultured with antigen presenting cell subsets. a Representative dot plot of CD4 ${ }^{+} \mathrm{T}-$ cells co-cultured with antigen presenting cell (APC) subpopulations day 5 post infection with NL(AD8) $\Delta$ nef-EGFP. Non-proliferating (eFluor670 hi), nonproductively infected (EGFP $\left.{ }^{-}\right)$T-cells were sorted 5 days following infection. $\mathbf{b}$ EGFP expression in the total cell cultures at day 5 post-infection was used as a measure of productive infection. c Total and post-integrated latency was stimulated from eFluor670 hiEGFP- ${ }^{-}$cells with anti-CD3/CD28 and IL-7 for 3 days and EGFP expression was quantified using flow cytometry. Representative dot plots show EGFP expression following stimulation of eFluor670 ${ }^{\text {hi }}$ EFPP $^{-}$sorted CD4 ${ }^{+}$T-cells in the absence (-L8 plot; total latency) and presence (+L8 plot; post integration latency) of the integrase inhibitor L8. d The frequency of total and e post-integration latent infection in resting CD4 ${ }^{+}$T-cells following co-culture with APC subpopulations. f Correlation of the frequency of productive infection and post-integrated latency $(+L 8)$ in each APC-T-cell co-culture. Each condition is identified by a different color and/or symbol. For all other panels, columns represent the median and open circles represent results from individual donors. Significant differences between conditions was measured by Wilcoxon matched pairs signed rank test where ${ }^{*} p \leq 0.05$

genecodis.cnb.csic.es), identified 285 known genes expressed in: membrane, plasma membrane, integral to membrane, integral to plasma membrane and cell junction ([37-39]; Fig. 5a). Of these, 53 protein-encoding genes that could establish cell contact with $\mathrm{CD} 4^{+} \mathrm{T}$-cells and potentially induce $\mathrm{T}$-cell signaling were selected
(Table 1, Additional file 2: Table S1). Functionally these genes included; cellular adhesion (32 genes), antigen presentation (1 gene), T-cell activation ( 9 genes), immune checkpoints (5 genes), regulation of apoptosis (5 gene), and an unknown protein (1 genes). We further analysed the role of each gene in HIV-1 infection of DC and 


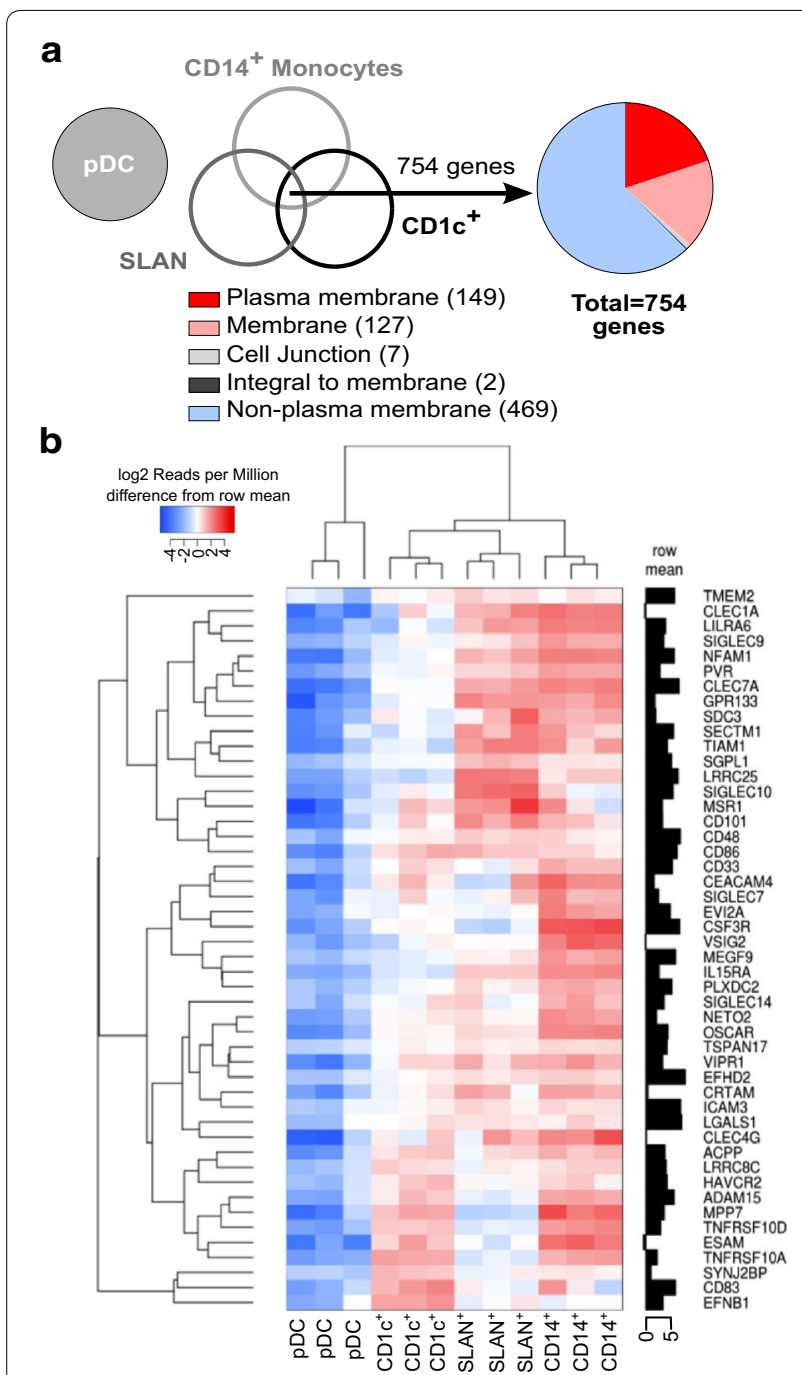

Fig. 5 Comparison of gene expression between latency inducing and non-inducing antigen presenting cell subpopulations using RNAseq. a Gene expression profiles common to the latency inducing APC subpopulations ( $\mathrm{CD} 1 \mathrm{c}^{+} \mathrm{mDC}, \mathrm{SLAN}{ }^{+} \mathrm{mDC}$ and $\mathrm{CD} 14^{+}$monocytes) compared with non-latency inducing APC (pDC) were selected (fold change $\geq 2, p<0.01$ ). Using GeneCodis, these 754 genes were categorised according to cellular compartment expression. $\mathbf{b}$ Encoded proteins expressed on APC surface and membrane compartments were further analysed for ability to signal to T-cells and involvement in HIV-1 infection. Representative heat map with >twofold differential gene expression of genes able to signal to T-cells, which are differentially expressed between latency inducing $\left(C D 1 c^{+} \mathrm{mDC}, \mathrm{SLAN}^{+}\right.$ $\mathrm{mDC}$ and $\mathrm{CD} 14^{+}$monocytes) and non-inducing APC subpopulations $(\mathrm{pDC})$

$\mathrm{CD} 44^{+}$T-cells using a PubMed search for the interactions between DC and T-cells, and potential roles in the establishment of HIV-1 latency (Additional file 2: Table S1).

We performed the same comparisons between selected APC subpopulations using our previously published microarray data [40] and found 27 genes that could potentially induce T-cell signalling (Additional file 4: Figure S2; Additional file 5: Table S2; [40]). Five of these genes were common between microarray and RNAseq analyses, seven genes shared protein family and thirteen genes fell outside of significance (cut off of $\mathrm{p}<0.01$ ), often with inconsistent replicates $(\mathrm{n}=3)$. The common genes included C-type lectin domain family 7 member $A$ (CLEC-7A), endoglin, intracellular adhesion molecule 3 (ICAM-3), sialic acid-binding immunoglobulin-type lectins (SIGLEC)-10 and CD1d. CD1d is involved in lipid antigen presentation to T-cells, while the other 4 surface expressed proteins are involved in cellular adhesion [41]. The common protein families included the SIGLEC family, CLEC family, leukocyte associated immunoglobulin like receptor (LILRA) family, G-Protein coupled receptor (GCPR) family and the tumor necrosis factor (TNF) receptor superfamily.

\section{Discussion}

Latently infected cells are infrequent in HIV-1-infected patients on CART, and therefore robust in vitro models are needed to better understand the establishment and maintenance of latent infection. We have now shown that multiple APCs, in addition to $\mathrm{mDC}$, are able to induce HIV-1 latency in non-proliferating $\mathrm{CD}^{+} \mathrm{T}$ cells [14]. Here, we have shown that the myeloid lineage cells capable of producing latent $\mathrm{T}$-cell infection include subpopulations of blood derived $\mathrm{mDC}$; $\mathrm{CD} 1 \mathrm{c}^{+}, \mathrm{SLAN}^{+} \mathrm{DC}$ and $\mathrm{CD} 14^{+}$monocytes, and confirmed that $\mathrm{pDC}$ are distinct in not generating latent infection. We have used RNA-seq analysis to define genes differentially expressed between APC subpopulations that could $\left(\mathrm{CD} 1 \mathrm{c}^{+}, \mathrm{SLAN}^{+}, \mathrm{CD} 14^{+}\right.$ monocytes) and could not induce latent infection (pDC), and identified genes mediating cell adhesion, T-cell activation, immune checkpoints (IC) and regulation of apoptosis as important pathways differentially upregulated in the APC that are able to induce latent infection.

Our results show that multiple blood derived $\mathrm{mDC}$ subsets can induce latent infection in non-proliferating $\mathrm{CD}_{4}^{+} \mathrm{T}$-cells, suggesting that this observation may extend to other DC and myeloid lineage cells, such as LC and dermal DC (DDC) though they may have different ontogeny [42-44]. It is likely that $\mathrm{mDC}$ and monocyte lineage cells in lymphoid tissue, skin, mucosal surfaces, gastrointestinal tract (GIT) and sites of inflammation could allow seeding of $\mathrm{CD} 4^{+} \mathrm{T}$-cell viral reservoirs early following infection or during ART in tissue sites were cART penetration may not be optimal [45].

We observed a trend between the ability of the different APCs to induce latent infection and efficient T-cell proliferation. This suggests that there may be a common mechanism for the induction of T-cell proliferation and induction of latent infection, even in non-proliferating cells, perhaps through a bystander mechanism. Efficient 
Table 1 Effects on HIV infection of genes differentially expressed by latency inducing and non-inducing antigen presenting cell subpopulations using RNA-seq

\begin{tabular}{|c|c|c|c|c|c|c|c|}
\hline \multirow[t]{2}{*}{ Gene name } & \multirow[t]{2}{*}{ Gene symbol } & \multicolumn{6}{|l|}{ Function } \\
\hline & & $\begin{array}{l}\text { Antigen } \\
\text { presentation }\end{array}$ & $\begin{array}{l}\text { Apoptosis } \\
\text { regulation }\end{array}$ & $\begin{array}{l}\text { Cell proximity } \\
\text { presentation }\end{array}$ & $\begin{array}{l}\text { Immune } \\
\text { checkpoint } \\
\text { blocker }\end{array}$ & $\begin{array}{l}\text { T-cell } \\
\text { activation }\end{array}$ & Unknown \\
\hline $\begin{array}{l}\text { Number of genes } \\
\text { expressed in } \\
\text { each category }\end{array}$ & & 1 & 5 & 32 & 5 & 9 & 1 \\
\hline CD1d molecule & CD1d & $--^{* * * *}$ & & & & & \\
\hline $\begin{array}{l}\text { Lectin, galactoside- } \\
\text { binding, soluble, } \\
1\end{array}$ & LGALS1 & & + & & & & \\
\hline $\begin{array}{l}\text { Vasoactive intes- } \\
\text { tinal peptide } \\
\text { receptor } 1\end{array}$ & VIPR1 & & $+^{*}$ & & & & \\
\hline $\begin{array}{l}\text { EF-hand domain } \\
\text { family, member } \\
\text { D2 }\end{array}$ & EFHD2 & & - & & & & \\
\hline $\begin{array}{l}\text { Tumor necrosis } \\
\text { factor receptor } \\
\text { superfamily, } \\
\text { member } 10 a\end{array}$ & TNFRSF10A & & + & & & & \\
\hline $\begin{array}{l}\text { Tumor necrosis } \\
\text { factor receptor } \\
\text { superfamily, } \\
\text { member } 10 d \text {, } \\
\text { decoy with } \\
\text { truncated death } \\
\text { domain }\end{array}$ & TNFRSF10D & & + & & & & \\
\hline $\begin{array}{l}\text { Acid phosphatase, } \\
\text { prostate }\end{array}$ & ACPP & & & + & & & \\
\hline $\begin{array}{l}\text { ADAM metal- } \\
\text { lopeptidase } \\
\text { domain } 15\end{array}$ & ADAM15 & & & + & & & \\
\hline $\begin{array}{l}\text { Integrin, beta } 2 \\
\text { (complement } \\
\text { component } 3 \\
\text { receptor } 3 \text { and } 4 \\
\text { subunit) }\end{array}$ & CD18 & & & $++^{* * * *}$ & & & \\
\hline $\begin{array}{l}\text { Carcinoembryonic } \\
\text { antigen-related } \\
\text { cell adhesion } \\
\text { molecule } 4\end{array}$ & CEACAM4 & & & + & & & \\
\hline $\begin{array}{l}\text { C-type lectin } \\
\text { domain family 4, } \\
\text { member G }\end{array}$ & CLEC4G & & & $--^{* * * *}$ & & & \\
\hline $\begin{array}{l}\text { C-type lectin } \\
\text { domain family } 7, \\
\text { member A }\end{array}$ & CLECTA & & & $+^{*}$ & & & \\
\hline $\begin{array}{l}\text { Cytotoxic and } \\
\text { regulatory T cell } \\
\text { molecule }\end{array}$ & CRTAM & & & $-^{* *}$ & & & \\
\hline $\begin{array}{l}\text { Colony stimulating } \\
\text { factor } 3 \text { receptor } \\
\text { (granulocyte) }\end{array}$ & CSF3R & & & $+^{*}$ & & & \\
\hline Ephrin-B1 & EFNB1 & & & - & & & \\
\hline Endoglin & END & & & $+^{*}$ & & & \\
\hline $\begin{array}{l}\text { Endothelial cell } \\
\text { adhesion mol- } \\
\text { ecule }\end{array}$ & ESAM & & & + & & & \\
\hline
\end{tabular}


Table 1 continued

\begin{tabular}{|c|c|c|c|c|c|c|c|}
\hline \multirow[t]{2}{*}{ Gene name } & \multirow[t]{2}{*}{ Gene symbol } & \multicolumn{6}{|l|}{ Function } \\
\hline & & $\begin{array}{l}\text { Antigen } \\
\text { presentation }\end{array}$ & $\begin{array}{l}\text { Apoptosis } \\
\text { regulation }\end{array}$ & $\begin{array}{l}\text { Cell proximity } \\
\text { presentation }\end{array}$ & $\begin{array}{l}\text { Immune } \\
\text { checkpoint } \\
\text { blocker }\end{array}$ & $\begin{array}{l}\mathrm{T} \text {-cell } \\
\text { activation }\end{array}$ & Unknown \\
\hline $\begin{array}{l}\text { G protein-coupled } \\
\text { receptor } 133\end{array}$ & GPR133 & & & + & & & \\
\hline $\begin{array}{l}\text { Intercellular adhe- } \\
\text { sion molecule } 3\end{array}$ & ICAM3 & & & $+^{*}$ & & & \\
\hline $\begin{array}{l}\text { Leucine rich repeat } \\
\text { containing } 8 \\
\text { family, member } C\end{array}$ & LRRC8C & & & + & & & \\
\hline $\begin{array}{l}\text { Multiple EGF-like- } \\
\text { domains } 9\end{array}$ & MEGF9 & & & + & & & \\
\hline $\begin{array}{l}\text { Membrane protein, } \\
\text { palmitoylated } \\
7 \text { (MAGUK p55 } \\
\text { subfamily mem- } \\
\text { ber 7) }\end{array}$ & MPP7 & & & + & & & \\
\hline $\begin{array}{l}\text { Macrophage scav- } \\
\text { enger receptor } 1\end{array}$ & MSR1 & & & + & & & \\
\hline $\begin{array}{l}\text { Osteoclast associ- } \\
\text { ated, immuno- } \\
\text { globulin-like } \\
\text { receptor }\end{array}$ & OSCAR & & & + & & & \\
\hline $\begin{array}{r}\text { Plexin domain } \\
\text { containing } 2\end{array}$ & PLXDC2 & & & + & & & \\
\hline Syndecan 3 & SDC3 & & & $+^{*}$ & & & \\
\hline CD33 molecule & CD33 & & & - & - & & \\
\hline $\begin{array}{l}\text { Sphingosine- } \\
\text { 1-phosphate } \\
\text { lyase } 1\end{array}$ & SGPL1 & & & + & + & & \\
\hline $\begin{array}{l}\text { Sialic acid binding } \\
\text { Ig-likelectin } 10\end{array}$ & SIGLEC10 & & & $-^{*}$ & - & & \\
\hline $\begin{array}{l}\text { Sialic acid binding } \\
\text { Ig-like lectin } 7\end{array}$ & SIGLEC7 & & & $+^{* *}$ & + & & \\
\hline $\begin{array}{l}\text { Sialic acid binding } \\
\text { Ig-like lectin } 9\end{array}$ & SIGLEC9 & & & - & - & & \\
\hline $\begin{array}{l}\text { Synaptojanin } 2 \\
\text { binding protein }\end{array}$ & SYNJ2BP & & & + & + & & \\
\hline $\begin{array}{l}\text { T-cell lymphoma } \\
\text { invasion and } \\
\text { metastasis } 1\end{array}$ & TIAM1 & & & $+^{*}$ & + & & \\
\hline $\begin{array}{l}\text { Transmembrane } \\
\text { protein } 2\end{array}$ & TMEM2 & & & + & + & & \\
\hline Tetraspanin 17 & TSPAN17 & & & - & - & & \\
\hline $\begin{array}{l}\text { C-type lectin } \\
\text { domain family } 1, \\
\text { member A }\end{array}$ & CLEC1A & & & + & & + & \\
\hline $\begin{array}{l}\text { Sialic acid binding } \\
\text { Ig-like lectin } 14\end{array}$ & SIGLEC14 & & & + & & + & \\
\hline CD101 molecule & CD101 & & & & - & & \\
\hline CD52 molecule & CD52 & & - & & - & & \\
\hline $\begin{array}{l}\text { Hepatitis A virus } \\
\text { cellular recep- } \\
\text { tor } 2\end{array}$ & HAVR2/Tim-3 & & & & $-^{* *}$ & & \\
\hline
\end{tabular}


Table 1 continued

\begin{tabular}{|c|c|c|c|c|c|c|c|}
\hline \multirow[t]{2}{*}{ Gene name } & \multirow[t]{2}{*}{ Gene symbol } & \multicolumn{6}{|l|}{ Function } \\
\hline & & $\begin{array}{l}\text { Antigen } \\
\text { presentation }\end{array}$ & $\begin{array}{l}\text { Apoptosis } \\
\text { regulation }\end{array}$ & $\begin{array}{l}\text { Cell proximity } \\
\text { presentation }\end{array}$ & $\begin{array}{l}\text { Immune } \\
\text { checkpoint } \\
\text { blocker }\end{array}$ & $\begin{array}{l}\mathrm{T} \text {-cell } \\
\text { activation }\end{array}$ & Unknown \\
\hline $\begin{array}{l}\text { Leukocyte } \\
\text { immunoglobu- } \\
\text { lin-like receptor, } \\
\text { subfamily A (with } \\
\text { TM domain), } \\
\text { member } 6\end{array}$ & LILRA6 & & & & - & & \\
\hline Poliovirus receptor & PVR & & & & $+^{*}$ & & \\
\hline $\begin{array}{l}\text { Neuropilin (NRP) } \\
\text { and tolloid (TLL)- } \\
\text { like } 2\end{array}$ & NETO2 & & & & + & & \\
\hline CD48 molecule & CD48 & & & & & $0^{* *}$ & \\
\hline $\begin{array}{l}\text { Interleukin } 15 \\
\text { receptor, alpha }\end{array}$ & IL15RA & & & & & $-{ }^{* *}$ & \\
\hline $\begin{array}{l}\text { Leucine rich repeat } \\
\text { containing } 25\end{array}$ & LRRC25 & & & & & + & \\
\hline $\begin{array}{l}\text { NFAT activating } \\
\text { protein with } \\
\text { ITAM motif } 1\end{array}$ & NFAM1 & & & & & + & \\
\hline $\begin{array}{l}\text { Secreted and trans- } \\
\text { membrane } 1\end{array}$ & SECTM1 & & & & & + & \\
\hline $\begin{array}{l}\text { V-set and immuno- } \\
\text { globulin domain } \\
\text { containing } 2\end{array}$ & VSIG2 & & & & & + & \\
\hline CD300e molecule & CD300e & & & & & + & \\
\hline CD83 molecule & CD83 & & & & & $0^{* *}$ & \\
\hline CD86 molecule & CD86 & & & & & $0^{* *}$ & \\
\hline $\begin{array}{l}\text { Ecotropic viral inte- } \\
\text { gration site } 2 \mathrm{~A}\end{array}$ & EVI2A & & & & & & + \\
\hline
\end{tabular}

The functional category shown were determined by the description from the DAVID (http://david.abcc.ncifcrf.gov/) and GeneCards (http://genecards.org/) databases + , increased latent infection; -, inhibition of virus expression, 0 , undefined. Genes that were common to the RNA-seq and microarray generated gene lists are in italics. * represent a role in HIV infection of either DC $(*)$ or T-cell ${ }^{* *}$. . Data in Table 1 is presented with additional detail and references in Additional file 3: Supplementary references

T-cell proliferation is favoured by the formation of an immunological synapse $[46,47]$ with cellular proximity [48], major-histocompatibility complex (MHC)-T-cell receptor (TcR) interaction and co-stimulation [49-52]. ICAM-1 interaction with leukocyte function-associated antigen (LFA)-1 can facilitate induction of latent infection in the DC-T-cell model [14], while in other models of in vitro latency CD2 expression, a molecule that binds to LFA-3, was increased on latently infected cells [53]. A large portion (60\%) of genes identified in the gene expression analysis mediates cellular proximity and cell adhesion. Taken together these data suggest that cell adhesion/contact is important in the induction of latency. However, identification of a single specific adhesion molecule critical for the induction of latent infection is likely limited by functional redundancy in mediators of APCT-cells interactions.
Compared to the other DCs, the pDC were least efficient for T-cell proliferation and induced significantly less productive and latent infection compared to $\mathrm{mDC}$. The differences between $\mathrm{mDC}$ and $\mathrm{pDC}$ in induction of productive infection $[54,55]$ and suppression of virus production has been observed previously [14]. We have also previously shown that $\mathrm{pDC}$ were unable to induce HIV-1 latency, and that there was a more substantial suppressive effect on the establishment of latency compared to productive infection. We and others have shown multiple differences between $\mathrm{mDC}$ and $\mathrm{pDC}$ that may reduce the ability of pDC to establish close interactions with T-cells $[26,40,56,57]$, which in combination with increased type-I IFN secretion from pDC may inhibit the capacity of pDC to establish latency in T-cells.

The ability of B-cells to induce latent infection in nonproliferating $\mathrm{CD} 4^{+} \mathrm{T}$-cells was also tested in this study as 
B-cells express MHC-II, circulate through LN, and have been reported to transfer HIV-1 infection to T-cells [58]. Induction of latency occurred only at low level and was only in the form of pre-integration latency suggesting that B-cells lack factors that facilitate efficient induction of post-integration latency.

Comparison of APC subpopulations that could and could not induce latent infection in non-proliferating $\mathrm{CD} 4^{+}$T-cells identified several functions that may be important in the establishment of latency, including cell adhesion, IC, T-cell co-stimulation, antigen presentation and regulation of apoptosis. The IC, programmed death receptor (PD)-1, is proposed to play a role in the establishment and/or maintenance of HIV-1 latency [59, 60]. Engagement of ICs, led to reduced T-cell activation by inhibition of signaling cascades, as well as physical inhibition of the formation of lipid rafts and cellular interactions [61]. In this study, we observed an up-regulation of the ICs; CD101, T-cell immunoglobulin mucin-3 (Tim-3, HAVR2), leukocyte immunoglobulinlike receptor member 6 (LILR6) and CD52, on latency inducing APC subpopulations when compared to pDC. IC expression may be important for the establishment of HIV-1 latency in this model, but further work is required to confirm this.

Additionally, we identified differential expression of the SIGLEC family of proteins between APC subpopulations that could and could not induce latent infection. We specifically found SIGLEC 5, 7, 9, 10 and 14 to be upregulated on latency inducing APCs. From this family, SIGLEC 3, 5-11 have all been implicated in the inhibition of T-cell activation [62-64]. SIGLEC 5 has been shown to inhibit T-cell activation in chimpanzees, where blockade of SIGLEC 5 led to increased T-cell activation, and transfection of SIGLEC 5 into SIGLEC negative cells reduced T-cell activation [64-67]. SIGLEC 10 is hypothesized to have similar function in inhibition of T-cell activation $[68,69]$. Together these data suggest that SIGLEC 5 or 10 binding to its ligand on the $\mathrm{CD} 4^{+} \mathrm{T}$-cell may reduce T-cell activation, reduce productive infection and potentially promote latent infection. This is a novel association but further work will be required to explore any direct effects of SIGLEC proteins and the establishment of latency.

\section{Conclusion}

This study has established that multiple myeloid lineage APC subpopulations can facilitate latent infection in resting $\mathrm{CD} 4^{+}$T-cells. Particularly important is the observation that $\mathrm{CD} 14^{+}$monocytes can induce latent infection in resting $\mathrm{CD} 4^{+} \mathrm{T}$-cells. The use of $\mathrm{CD} 14^{+}$monocytes will greatly enhance the utility of this model. In addition, through a comparative analysis of APC populations, we have identified new pathways that may potentially be involved in the establishment and/or maintenance of HIV-1 latency. Inhibition of key pathways involved in mDC-T-cell interactions and HIV-1 latency may provide novel targets to eliminate HIV-1 latency.

\section{Methods \\ Isolation and preparation of resting $\mathrm{CD} 4^{+} \mathrm{T}$-cells and B-cells}

PBMC were isolated by Ficoll-Paque density gradient centrifugation (GE Healthcare, Chalfont St. Giles, UK) from healthy buffy coats obtained from the Australian Red Cross. PBMC were further separated into three populations by counter-current elutriation using Beckman J-6M/E centrifuge equipped with a JE 5.0 rotor (Beckman Coulter, Pasedena, CA, USA; [70]). The three fractions were isolated at rates of 12 (small lymphocytes), 16 (large lymphocytes) and 20 (DC/Monocytes fractions) $\mathrm{ml} / \mathrm{min}$. Resting $\mathrm{CD}^{+}{ }^{+} \mathrm{T}$-cells, negative for the activation markers CD69 and HLA-DR, were sorted from the "small lymphocyte" fraction, as previously described [14], with a purity always $>98 \%$. B-cells were isolated with a purity of $\geq 90 \%$ from the "small and large lymphocyte" fractions using positive magnetic bead selection on an autoMACS (Miltenyi) using anti-CD19+ ${ }^{+}$hybridoma (clone FMC63) and anti-IgG microbeads (Miltenyi, Bergisch Gladbach, Germany).

\section{Isolation of DC and monocytes}

The remaining elutriated fraction, containing the larger cells $(20 \mathrm{ml} / \mathrm{min}$ ), was used to isolate DC and monocytes. The large cell fraction was first stained with antibodies specific for the DC subsets, which included CD1c-APC (Miltenyi), CD141-VioBlue (Miltenyi), CD123-PE (BD BioSciences, Franklin Lakes, NJ, USA) and SLAN-FITC (Miltenyi), and labeled with anti-IgG beads (Miltenyi). DC were then isolated using an AutoMACS (Miltenyi) into positive and negative fractions. The positive fraction (DC enriched) was further sorted into four DC subsets: $\mathrm{CD} 1 \mathrm{c}^{+} \mathrm{mDC}, \mathrm{SLAN}^{+} \mathrm{DC}, \mathrm{CD} 141^{+} \mathrm{mDC}$ and $\mathrm{CD}_{123^{+}} \mathrm{pDC}$, using a FACSAria (BD BioSciences). The negative fraction (DC depleted/mono) was stained with anti-CD14-FITC and anti-CD16-PE (BD Biosciences) antibodies, labeled with IgG beads (Miltenyi) and a positive selection performed using an AutoMACS (Miltenyi) to obtain a bulk monocyte population. These cells were further sorted to obtain the $\mathrm{CD} 14^{+} \mathrm{CD} 16^{-}\left(\mathrm{CD} 14^{+}\right)$and $\mathrm{CD} 16^{+} \mathrm{CD} 14^{\text {lo }}\left(\mathrm{CD} 16^{+}\right)$monocyte subsets using a FACSAria. Cell populations with a purity $\geq 90 \%$ were used, as determined by flow cytometry (LSR II or FACSAria; BD Bioscience). In the event of low yields of some APC subpopulation, the experiment was continued without that population. In these experiments the missing data was 
omitted from the plots and therefore not every donor has data shown for all conditions tested.

\section{Imaging antigen presenting cell subpopulations}

After isolation, each antigen presenting cell (APC) subpopulation was cultured in RF10 media (RPMI 1640; Life Technologies, Carlsbad, CA, USA), supplemented with $10 \%$ fetal bovine serum (FBS; Interpath, Heidelberg, Australia), Penicillin-Streptomycin-Glutamine (PSG; Life Technologies) for $1-2 \mathrm{~h}$ at $37^{\circ} \mathrm{C}$ in glass-bottom imaging plates ( $\mu$-slide, ibidi, Martinsried, Germany). Ten representative images were captured on a CCD camera through a $10 \times 0.3 \mathrm{NA}$ lens on a Olympus IX51 microscope and annotated with ImageJ software.

\section{Syngeneic mixed leukocyte reactions}

Resting $\mathrm{CD}_{4}^{+}$T-cells were labeled with eFluor670 and co-cultured with decreasing concentrations of each APC subpopulation; $\log 1$ (10:1), 2 (100:1) and 3 (1000:1), in the absence (syngeneic) or presence of superantigen SEB (10 ng/mL; Sigma). At day 5, cells were harvested and labeled with antibody against CD3 (V450, BD Bioscience). Cells were analysed by flow for T-cells that proliferated and therefore expressed low levels of eFluor670.

\section{Viral plasmids, virus preparation and infection}

In all experiments, we used HIV-1 NL4.3 plasmid backbone with an AD8 envelope and EGFP inserted in the nef open reading frame at position $75(\mathrm{NL}(\mathrm{AD} 8) \Delta n e f E G F P)$ [14], kindly provided by Damian Purcell, University of Melbourne (Melbourne, Australia). Viral stocks were generated by FuGene (Promega, Madison, WI, USA) transfection of $293 \mathrm{~T}$ cells as previously described [14]. Cells were infected at an MOI of 0.5 , as determined by limiting dilution in PHA-stimulated PBMC using the Reed and Muench method [71].

\section{In vitro latency model}

Resting $\mathrm{CD}^{+}{ }^{+} \mathrm{T}$-cells were labeled with the proliferation dye eFluor670 and cultured alone or with one of seven sorted syngeneic APC subpopulations at a ratio of 10:1 for $24 \mathrm{~h}$ in IL-2 (2U/mL, Roche Diagnostics, Basel, Switzerland) supplemented RF10 media. APC included monocyte subpopulations $\left(\mathrm{CD} 14^{+} \mathrm{CD} 16^{-}\right.$and $\mathrm{CD} 14^{\mathrm{lo}} \mathrm{CD} 16^{+}$), DC subpopulations (pDC, $\mathrm{CD} 1 \mathrm{c}^{+}$, $\mathrm{CD}_{14} 1^{+}$and $\mathrm{SLAN}^{+}$), and B-cells. Co-cultures were then infected with NL(AD8) $\Delta$ nefEGFP for $2 \mathrm{~h}$, after which time excess virus was washed away and cells were cultured for an additional 5 days. In order to compare APC stimulatory capacity between APC-T-cell co-cultures, at day 3 post-infection, cells were stained with anti-CD3V450 (BD Biosciences) to differentiate between T-cell and APC, and the proportion of proliferated (eFluor670 ${ }^{\text {lo }}$ )
CD4 ${ }^{+}$T-cells were determined. Day 3 was used because this is when productive infection reached is maximum and remained high until day 5 (unpublished data). Additional APC-T-cell ratio's were not used due to low APC yields. At day 5 post-infection, productive infection was determined by EGFP expression and non-proliferating, non-productively infected (eFluor670 ${ }^{\text {hi }}$ EGFP $^{-}$) $\mathrm{CD}_{4}^{+}$ T-cells were sorted using a FACSAria.

\section{Reactivation of latency from resting T-cells}

Latent infection in the sorted, non-proliferating $\mathrm{CD}_{4}^{+}$ T-cells (eFluor670 ${ }^{\text {hi }} \mathrm{EGFP}^{-}$) was determined by comparison of stimulated with un-stimulated T-cells sorted from APC-T-cell co-cultures (control). $1 \times 10^{5}$ sorted $\mathrm{CD}^{+}{ }^{+}$T-cells were stimulated with immobilized antiCD3 (7 $\mu \mathrm{g} / \mathrm{ml}$; Beckman Coulter), in RF10 media supplemented with CD28 (5 $\mu \mathrm{g} / \mathrm{mL}$; BD Biosciences), IL-7 (50 ng/mL; Sigma, St Louis, MO, USA), IL-2 (5U/mL; Roche), with (post-integrated latency) or without (total latency: pre- and post-integrated latency) integrase inhibitor L8 ( $1 \mu \mathrm{M}$; Merck, White House Station, NJ, USA). The concentration of L8 was determined previously by titration of L8 in phytohaemagglutinin (PHA; $10 \mu \mathrm{g} /$ $\mathrm{mL}$ ) activated PBMC infected with R5-EGFP virus at an MOI of 0.5 , same concentration usedin co-cultures, and showed productive infection was completely blocked at $1 \mu \mathrm{M}$. This concentration used for all subsequent experiments. Cells were harvested after $72 \mathrm{~h}$ of stimulation and EGFP expression was quantified on the FacsCalibur (BD BioSciences).

In some experiments PHA (10ug/mL) and IL-2 (10 U/ $\mathrm{mL}$ ) stimulated feeder PBMC were used to activate T-cells as a measure of inducing virus replication form latency, as described previously [14].

\section{Cell preparation for next generation sequencing and generation of gene lists}

APC from 3 donors were sorted as described above to obtain $\mathrm{mDC}$ subpopulations $\mathrm{CD}_{1}{ }^{+}, \mathrm{SLAN}^{+}, \mathrm{CD} 14^{+}$ monocytes and $\mathrm{pDC}$ which were immediately stored in RLT buffer (Qiagen, Limburg, The Netherlands). Total RNA was isolated from low cell number samples $(<500,000$ cells) using Qiagen ALL prep micro kits (Qiagen), while RNA from samples with $>500,000$ cells were isolated using Qiagen RNA easy mini kits (Qiagen), according to the manufacturer's instructions. Total RNA content varied from 270.0 to $1879.7 \mathrm{ng}$.

The Australian Gene Research Facility Ltd (AGRF, Melbourne, Australia) prepared cDNA libraries, which were multiplexed on the Illumina HiSeq 2000 (Illumina, San Diago, CA, USA). For gene expression analysis, single reads were selected with 20 million reads of $50 \mathrm{bp}$ read size gathered. The RNA-seq reads were aligned to the 
human reference hg19 using the TopHat2 aligner [72, 73] and quantified using htseq-count [74]. Mapping rates for RNA seq are shown (Additional file 6: Table S3). Differential expression was calculated using Voom/Limma [75] and visualization performed using Degust [76] (http:// victorian-bioinformatics-consortium.github.io/degust/) and Vennt [77] (http://drpowell.github.io/vennt/). Genes with fewer than 10 reads across every sample were removed from the analysis.

APC subsets were categorized as latency-inducing and latency-non-inducing subsets. Using a fold change of greater than 2 and false discovery rate (FDR) of 0.01 , we identified 754 genes that were significantly upregulated in latency inducing populations $\left(\mathrm{CD} 1 \mathrm{c}^{+} \mathrm{mDC}, \mathrm{CD} 14^{+}\right.$ monocytes, SLAN ${ }^{+} \mathrm{DC}$ ) compared to latency non-inducing populations (pDC; Fig. 4). As direct cell contact is required for the establishment of $\mathrm{mDC}$ induced latency, only protein encoding genes from APC implicated in cell contact were selected using the GeneCodis database (http://genecodis.cnb.csic.es). We identified 285 genes from the initial list that encode for proteins known to be expressed on the plasma-membrane, membrane, integral to the plasma-membrane/membrane and cell junctions [37-39]. Finally, we manually curated this list to identify 53 genes known to be involved in T-cell signaling (Table 1; Additional file 1: Table S1). RNA-seq data is available through Gene Omnibus (GEO), serial number GSE70106.

As a comparison, we performed a similar analysis using our previously published microarray data using the same APC subpopulations [40]. Microarray data was kindly provided by Andrew Harman, Westmead Millennium Institute for Medical Research, Sydney University, Sydney [40]. The RNA extraction, labeling, hybridization, data processing, and analysis procedures used by Harman et al. are described previously for the cDNA gene array [78] and Illumina arrays [79]. Hybridization and data processing was performed by AGRF using sentrix human 6 v2 expression chips (Illumina).

\section{Ethics approval}

The use of blood samples from normal donors for this study was approved by the Alfred Hospital (HREC 156/11) and Monash University (CF11/1888) Human Research and Ethics Committees. Donors were recruited by the Red Cross Blood Transfusion Service as normal blood donors and all provided written informed consent for the use of their blood products for the research.

\section{Statistical analysis}

Differences between experimental conditions were analyzed using Wilcoxon matched pairs signed rank test $(\mathrm{n} \geq 5)$ or paired student T-test $(\mathrm{n}<5)$ on GraphPad Prism (Version 6). P-values $\leq 0.05$ were considered significant.
Differentially expressed RNA-seq and microarray genes were found to be significant using ANOVA [40].

\section{Additional files}

Additional file 1: Figure S1. Multidimensional scaling (MDS) of sequenced APC subpopulations. RNA sequences were measured according to two dimensions, 1 (x-axis) and 2 (y-axis). Each dot represents an antigen presenting cell (APC) subpopulation sequence, as labeled, $n=3$. Clustering of dots is indicative of similar gene expression profiles.

Additional file 2: Table S1. Comparison of gene expression between latency inducing and non-inducing antigen presenting cell subpopulations using RNA-seq. Using the bioinformatics databases DAVID [80], Gen eCards and GeneCodis, cell compartment gene function was determine of each gene. Genes expressed on antigen presenting cell (APC)-surface with the ability to signal to T-cells were shortlisted and their role in HIV-1 infection and DC-T-cell interaction was further determined using PubMed. Genes that were common to the RNA-seq and microarray generated gene lists are in italics and underlined in Table 1. Acronyms used: intracellular adhesion molecules (ICAM), C-type lectin (CLEC), immunoglobulin (lg), T-cell immune-receptor with Ig and tyrosine-based inhibition motif (ITIM) domains (TIGIT), DNAX accessory molecule-1 (DNAM-1), cytotoxic and regulatory T-cell molecule (CRTAM), junction adhesion molecules (JAMs), blood brain barrier (BBB), leukocyte function antigen (LFA), dendritic cell-specific intercellular adhesion molecule-3-grabbing non-integrin (DCSIGN), galectin-1 (Gal-1), cysteine-dependent aspartate-directed proteases (caspase), factor for adipocyte differentiation 158 (FAD158), extracellular matrix (ECM), lymph node (LN), nuclear factor-kappa-B (NFkB), vascular endothelial growth factor (VEGF), major histocompatibility complex (MHC), T-cell receptor (TCR), cytotoxic T-lymphocyte-associated protein 4 (CTLA-4), TYRO protein tyrosine kinase-binding protein (TYROBP), interleukin (IL-), nuclear factor of activated T-cells (NFAT), vasoactive intestinal polypeptide receptor 1 (VIPR1), T-cell immunoglobulin mucin-3 (Tim-3), monocyte derived dendritic cells (MDDC), natural killer cells (NK), human T-lymphotropic virus (HTLV-1), NFAT activating protein with immune-receptor tyrosine-based activation motif (NFAM1, CNAIP), cortical thymocyte-like protein (CTH, CTXC), B-cell receptor (BCR), HIV-associated neurocognitive disorder (HAND), antibody dependent cellular cytotoxicity (ADCC), Fc receptor (FCR), scavenger receptor class-A-1 (SRA-1), epidermal growth factor like domain, multiple/protein 5/9 (EGFL5).

Additional file 3: Supplementary references to Table 1. Included is the literature documenting the association of specific genes found in this study and changes in HIV infection and expression.

Additional file 4: Figure S2. Differential gene expression assessed by microarray analysis between latency inducing and non-inducing antigen presenting cells. A. Microarray gene expression profiles of antigen presenting cell (APC) subpopulations that could induce latency $\left(C D 1 c^{+}\right.$, $\mathrm{SLAN}^{+}, \mathrm{CD}_{14}{ }^{+}$monocytes) in non-proliferating CD4 ${ }^{+}$T-cells were compared with APC subpopulations that could not induce latency (plasmacytoid (p)DC). Genes that were expressed in all 3 latency inducing APC subpopulations, $\mathrm{CD}_{1} c^{+}, \mathrm{SLAN}^{+}, \mathrm{CD}_{1} 4^{+}$monocytes, were categorized as candidate 3 , genes expressed in only 2 APC subpopulations were categorized as candidate 2 and genes expressed only in 1 APC subpopulation were categorized as candidate 1. B. Using the bioinformatics databases DAVID, GeneCards and GeneCodis, Candidate 2 and 3 gene lists were analyzed for cellular compartment and function. Genes expressed on the APC cell surface, with the ability to signal to T-cells were shortlisted. $\mathbf{C}$. Heat map shows differentially expressed genes with $\geq$ twofold differences between latency inducing APC subpopulations (CD14 ${ }^{+}$monocytes, $\mathrm{CD} \mathrm{c}^{+} \mathrm{mDC}$ and $\mathrm{SLAN}^{+} \mathrm{mDC}$ ) and non-latency inducing (pDC).

Additional file 5: Table S2. Comparison of gene expression between latency inducing and non-inducing antigen presenting cell subpopulations using microarray. Using the bioinformatics databases DAVID, GeneCards and GeneCodis, gene expression compartment and function was determined. Genes expressed on the antigen presenting cell (APC)surface with the ability to signal to T-cells were shortlisted.

Additional file 6: Table S3. Sequence mapping rates in RNA-seq. 


\section{Abbreviations}

APC: antigen presenting cell; CART: combination antiretroviral therapy; CLEC7A: C-type lectin domain family 7 member A; DC: dendritic cells; DDC: dermal dendritic cell; EGFP: emerald-green fluorescent protein; FBS: fetal bovine serum; FDR: false discovery rate; FC: fold change; GCPR: G-coupled protein receptor; GEO: gene Omnibus; GIT: gastrointestinal tract; HAVR2: Hepatitis A virus cellular receptor 2; HIV-1: human immunodeficiency virus; ICAM: intracelIular adhesion molecule 3; ICB: immune checkpoint blocker; IL-7: interluekin-7; IL-2: interluekin-2; LC: langerhan cell; LFA: leukocyte function associated antigen; LILR: leukocyte-associated immunoglobulin like receptor; LN: Iymph node; mDC: myeloid dendritic cell; MHC: major histocompatibility complex; MLR: mixed leukocyte reaction; Mono: monocyte; PBMC: peripheral blood mononuclear cells; PD-1: programmed death receptor-1; pDC: plasmacytoid dendritic cell; PHA: phytohemagglutinin; SEB: staphylococcal enterotoxin B; SIGLEC: sialic acid-binding immunoglobulin-type lectins; SLAN: 6-sulfo LacNAc;Tim-3: T-cell immunoglobulin mucin-3; TNF: tumor necrosis factor.

\section{Authors' contributions}

NK carried out cell isolations and infection experiments with the assistance of KC. CdfP and JA assisted with imaging experiments NK performed RNA isolation. DRP performed most of the bioinformatics analysis for RNA-seq data and with NK generated and analysed genes lists. Microarray analysis was completed by PUC and NK. PUC, NK and SRL conceived the study, and participated in its design and coordination. Manuscript was prepared by PUC, NK, VE and JA. All authors read and approved the final manuscript.

\section{Author details}

1 Department of Infectious Diseases, Alfred Hospital and Monash University, Melbourne, VIC 3004, Australia. ${ }^{2}$ Centre for Biomedical Research, Burnet Institute, Melbourne, VIC 3004, Australia. ${ }^{3}$ Victorian Life Science Computational Initiative, Parkville 3010, Australia. ${ }^{4}$ Monash Bioinformatics Platform, Monash University, Clayton 3800, Australia. ${ }^{5}$ Doherty Institute for Infection and Immunity, University of Melbourne, Melbourne 3010, Australia.

\section{Acknowledgements}

We thank Damian Purcell (University of Melbourne, Parkville, Australia) for providing us with the EGFP-reporter virus. We thank J. Le Masurier, M. Thomson, P. Donaldson and G. Paukovics (Alfred Medical Research and Educational Precinct (AMREP) Flow Cytometry Core Facility, Melbourne, Australia) for flow cytometric cell sorting. We thank the Australian Gene Research Facility Ltd (AGRF, Melbourne, Australia) for the guidance and support in processing of samples for RNA-seq. We thank A. Harman (Westmead Millennium Institute for Medical Research, Sydney University, Sydney, Australia) for access to microarray data, Jingling Zhou for assistance with elutriation protocol and Ajantha Solomon for assistance with RNA isolation techniques. We thank Renee van der Sluis for support in preparation of the manuscript.

\section{Funding}

NK is the recipient of the Australian Postgraduate Award (APA) (fund \# Q05201 6609004). S.R.L is an NHMRC practitioner fellow. This work was supported by NHMRC project grant 1041795 and National Institutes of Health Delany AIDS Research Enterprise (DARE) to find a cure Collaboratory (U19 Al096109).

\section{Compliance with ethical guidelines}

\section{Competing interests}

The authors declare that they have no competing interests.

Received: 13 April 2015 Accepted: 1 September 2015 Published online: 11 September 2015

\section{References}

1. Chun TW, Finzi D, Margolick J, Chadwick K, Schwartz D, Siliciano RF. In vivo fate of HIV-1-infected T cells: quantitative analysis of the transition to stable latency. Nat Med. 1995;1:1284-90.

2. Finzi D, Hermankova M, Pierson T, Carruth LM, Buck C, Chaisson RE, Quinn TC, Chadwick K, Margolick J, Brookmeyer R, Gallant J, Markowitz M, Ho DD, Richman DD, Siliciano RF. Identification of a reservoir for HIV-1 in patients on highly active antiretroviral therapy. Science. 1997;278:1295-300.

3. Hermankova M, Siliciano JD, Zhou Y, Monie D, Chadwick K, Margolick JB, Quinn TC, Siliciano RF. Analysis of human immunodeficiency virus type 1 gene expression in latently infected resting $C D 4^{+} T$ lymphocytes in vivo. J Virol. 2003;77:7383-92.

4. Stevenson M, Stanwick TL, Dempsey MP, Lamonica CA. HIV-1 replication is controlled at the level of T cell activation and proviral integration. EMBO J. 1990;9:1551-60.

5. Zack JA, Arrigo SJ, Weitsman SR, Go AS, Haislip A, Chen IS. HIV-1 entry into quiescent primary lymphocytes: molecular analysis reveals a labile, latent viral structure. Cell. 1990;61:213-22.

6. Zack JA, Haislip AM, Krogstad P, Chen IS. Incompletely reverse-transcribed human immunodeficiency virus type 1 genomes in quiescent cells can function as intermediates in the retroviral life cycle. J Virol. 1992;66:1717-25

7. Bosque A, Planelles V. Induction of HIV-1 latency and reactivation in primary memory $\mathrm{CD}^{+}{ }^{+} \mathrm{T}$ cells. Blood. 2009;1 13:58-65.

8. Marini A, Harper JM, Romerio F. An in vitro system to model the establishment and reactivation of HIV-1 latency. J Immunol. 2008;181:7713-20.

9. Sahu GK, Lee K, Ji J, Braciale V, Baron S, Cloyd MW. A novel in vitro system to generate and study latently HIV-infected long-lived normal CD4 ${ }^{+}$ T-lymphocytes. Virology. 2006;355:127-37.

10. Yang H-C, Xing S, Shan L, O'Connell K, Dinoso J, Shen A, Zhou Y, Shrum CK, Han Y, Liu JO, Zhang H, Margolick JB, Siliciano RF. Small-molecule screening using a human primary cell model of HIV latency identifies compounds that reverse latency without cellular activation. J Clin Invest. 2009;119:3473-86.

11. Pace MJ, Graf EH, Agosto LM, Mexas AM, Male F, Brady T, Bushman FD, O'Doherty U. Directly infected resting $C D 4^{+} T$ cells can produce HIV gag without spreading infection in a model of HIV latency. PLoS Pathog. 2012;8:e1002818-33.

12. Swiggard WJ, Baytop C, Yu JJ, Dai J, Li C, Schretzenmair R, Theodosopoulos T, O'Doherty U. Human immunodeficiency virus type 1 can establish latent infection in resting $\mathrm{CD}^{+} \mathrm{T}$ cells in the absence of activating stimuli. J Virol. 2005;79:14179-88.

13. Saleh S, Solomon A, Wightman F, Xhilaga M, Cameron PU, Lewin SR. CCR7 ligands CCL19 and CCL21 increase permissiveness of resting memory $\mathrm{CD}^{+} \mathrm{T}$ cells to HIV-1 infection: a novel model of HIV-1 latency. Blood. 2007;110:4161-4.

14. Evans VA, Kumar N, Filali A, Procopio FA, Yegorov O, Goulet J-P, Saleh S, Haddad EK, da Fonseca Pereira C, Ellenberg PC, Sekaly RP, Cameron PU, Lewin SR. Myeloid dendritic cells induce HIV-1 latency in non-proliferating CD4+ T Cells. PLoS Pathog. 2013;9:e1003799-813.

15. Shen A, Baker JJ, Scott GL, Davis YP, Ho Y-Y, Siliciano RF. Endothelial cell stimulation overcomes restriction and promotes productive and latent HIV-1 infection of resting CD4+ T Cells. J Virol. 2013;87:9768-79.

16. Hladik F, Sakchalathorn P, Ballweber L, Lentz G, Fialkow M, Eschenbach D, McElrath MJ. Initial events in establishing vaginal entry and infection by human immunodeficiency virus type-1. Immunity. 2007;26:257-70.

17. Hussain LA, Lehner T. Comparative investigation of Langerhans' cells and potential receptors for HIV in oral, genitourinary and rectal epithelia. Immunology. 1995;85:475-84.

18. Zaitseva M, Blauvelt A, Lee S, Lapham CK, Kiaus-Kovrun V, Mostowski H, Manischewitz J, Golding H. Expression and function of CCR5 and CXCR4 on human Langerhans cells and macrophages: implications for HIV primary infection. Nat Med. 1997;3:1369-75.

19. Cerovic V, Houston SA, Scott CL, Aumeunier A, Yrlid U, Mowat AM, Milling SWF. Intestinal CD103(-) dendritic cells migrate in lymph and prime effector T cells. Mucosal Immunol. 2012;6:104-113

20. Chu C-C, Ali N, Karagiannis P, Di Meglio P, Skowera A, Napolitano L, Barinaga G, Grys K, Sharif-Paghaleh E, Karagiannis SN, Peakman M, Lombardi G, Nestle FO. Resident CD141 (BDCA3) + dendritic cells in human skin produce IL-10 and induce regulatory T cells that suppress skin inflammation. J Exp Med. 2012;209:935-45.

21. Ginhoux F, Liu K, Helft J, Bogunovic M, Greter M, Hashimoto D, Price J, Yin N, Bromberg J, Lira SA, Stanley ER, Nussenzweig M, Merad M. The origin and development of nonlymphoid tissue CD103 + DCs. J Exp Med. 2009;206:3115-30.

22. Yu Cl, Becker C, Wang Y, Marches F, Helft J, Leboeuf M, Anguiano E, Pourpe S, Goller K, Pascual V, Banchereau J, Merad M, Palucka K. Human CD1c(+) 
dendritic cells drive the Differentiation of CD103(+) CD8(+) mucosal effector T cells via the cytokine TGF- $\beta$. Immunity. 2013;38:818-30.

23. Hänsel A, Günther C, Baran W, Bidier M, Lorenz HM, Schmitz M, Bachmann M, Döbel T, Enk AH, Schäkel K: Human 6-sulfo LacNAc (slan) dendritic cells have molecular and functional features of an important pro-inflammatory cell type in lupus erythematosus. J Autoimmun. 2012.

24. Qu C, Edwards EW, Tacke F, Angeli V, Llodrá J, Sanchez-Schmitz G, Garin A, Haque NS, Peters W, van Rooijen N, Sanchez-Torres C, Bromberg J, Charo IF, Jung S, Lira SA, Randolph GJ. Role of CCR8 and other chemokine pathways in the migration of monocyte-derived dendritic cells to lymph nodes. J Exp Med. 2004;200:1231-41.

25. Ginhoux F, Jung S. Monocytes and macrophages: developmental pathways and tissue homeostasis. Nat Rev Immunol. 2014;14:392-404.

26. MacDonald KPA, Munster DJ, Clark GJ, Dzionek A, Schmitz J, Hart DNJ. Characterization of human blood dendritic cell subsets. Blood. 2002;100:4512-20.

27. Nagasawa T. Microenvironmental niches in the bone marrow required for B-cell development. Nat Rev Immunol. 2006;6:107-16.

28. Rissoan M-C, Duhen T, Bridon J-M, Bendriss-Vermare N, Péronne C, Vis $B$ de $S$, Brière F, Bates EEM. Subtractive hybridization reveals the expression of immunoglobulinlike transcript 7, Eph-B1, granzyme B, and 3 novel transcripts in human plasmacytoid dendritic cells. Blood. 2002;100:3295-303.

29. Schäkel K, Mayer E, Federle C, Schmitz M, Riethmüller G, Rieber EP. A novel dendritic cell population in human blood: one-step immunomagnetic isolation by a specific $\mathrm{mAb}(\mathrm{M}-\mathrm{DC} 8)$ and in vitro priming of cytotoxic T lymphocytes. Eur J Immunol. 1998;28:4084-93.

30. Ziegler-Heitbrock L, Ancuta P, Crowe S, Dalod M, Grau V, Hart DN, Leenen PJM, Liu Y-J, MacPherson G, Randolph GJ, Scherberich J, Schmitz J, Shortman K, Sozzani S, Strobl H, Zembala M, Austyn JM, Lutz MB. Nomenclature of monocytes and dendritic cells in. Blood. 2010;116:e74-80.

31. Geissmann F, Jung S, Littman DR. Blood monocytes consist of two principal subsets with distinct migratory properties. Immunity. 2003;19:71-82.

32. O'Doherty U, Steinman RM, Peng M, Cameron PU, Gezelter S, Kopeloff I, Swiggard WJ, Pope M, Bhardwaj N. Dendritic cells freshly isolated from human blood express CD4 and mature into typical immunostimulatory dendritic cells after culture in monocyte-conditioned medium. J Exp Med. 1993;178:1067-76

33. Steinman RM, Cohn ZA. Identification of a novel cell type in peripheral lymphoid organs of mice. I. Morphology, quantitation, tissue distribution. J Exp Med. 1973;137:1142-62.

34. Ahn JH, Lee Y, Jeon C, Lee S-J, Lee B-H, Choi KD, Bae Y-S. Identification of the genes differentially expressed in human dendritic cell subsets by cDNA subtraction and microarray analysis. Blood. 2002;100:1742-54.

35. Huang Q, Liu D, Majewski P, Schulte LC, Korn JM, Young RA, Lander ES, Hacohen N. The plasticity of dendritic cell responses to pathogens and their components. Science. 2001;294:870-5.

36. Verdijk P, van Veelen PA, de Ru AH, Hensbergen PJ, Mizuno K, Koerten HK, Koning F, Tensen CP, Mommaas AM. Morphological changes during dendritic cell maturation correlate with cofilin activation and translocation to the cell membrane. Eur J Immunol. 2004;34:156-64

37. Carmona-Saez P, Chagoyen M, Tirado F, Carazo JM, Pascual-Montano A. GENECODIS: a web-based tool for finding significant concurrent annotations in gene lists. Genome Biol. 2007;8:R3.

38. Nogales-Cadenas R, Carmona-Saez P, Vazquez M, Vicente C, Yang X, Tirado F, Carazo JM, Pascual-Montano A. GeneCodis: interpreting gene lists through enrichment analysis and integration of diverse biological information. Nucleic Acids Res. 2009;37(Web Server issue):W317-22.

39. Tabas-Madrid D, Nogales-Cadenas R, Pascual-Montano A. GeneCodis3: a non-redundant and modular enrichment analysis tool for functional genomics. Nucleic Acids Res. 2012;4(Web Server issue):W478-83.

40. Harman AN, Bye CR, Nasr N, Sandgren KJ, Kim M, Mercier SK, Botting RA, Lewin SR, Cunningham AL, Cameron PU. Identification of lineage relationships and novel markers of blood and skin human dendritic cells. J Immunol Baltim Md. 1950;2013(190):66-79.

41. Kelly H, Mandraju R, Coelho-dos-Reis JGA, Tsuji M. Effects of HIV-1-induced CD1C and CD1d modulation and endogenous lipid presentation on CD1c-restricted T-cell activation. BMC Immunol. 2013;14:1-10.

42. Haniffa M, Shin A, Bigley V, McGovern N, Teo P, See P, Wasan PS, Wang X-N, Malinarich F, Malleret B, Larbi A, Tan P, Zhao H, Poidinger M, Pagan S, Cookson S, Dickinson R, Dimmick I, Jarrett RF, Renia L, Tam J, Song C,
Connolly J, Chan JKY, Gehring A, Bertoletti A, Collin M, Ginhoux F. Human tissues contain CD141 hi cross-presenting dendritic cells with functional homology to mouse CD103+ nonlymphoid dendritic cells. Immunity. 2012;37:60-73.

43. McGovern N, Schlitzer A, Gunawan M, Jardine L, Shin A, Poyner E, Green K, Dickinson R, Wang X-N, Low D, Best K, Covins S, Milne P, Pagan S, Aljefri K, Windebank M, Saavedra DM, Larbi A, Wasan PS, Duan K, Poidinger M, Bigley V, Ginhoux F, Collin M, Haniffa M. Human dermal CD14 ${ }^{+}$cells are a transient population of monocyte-derived macrophages. Immunity. 2014;41:465-77.

44. Satpathy AT, Wu X, Albring JC, Murphy KM. Re(de)fining the dendritic cell lineage. Nat Immunol. 2012;13:1145-54.

45. Trezza CR, Kashuba ADM: Pharmacokinetics of antiretrovirals in Genital Secretions and Anatomic Sites of HIV Transmission: Implications for HIV Prevention. Clin Pharmacokinet. 2014.

46. Revy P, Sospedra M, Barbour B, Trautmann A. Functional antigenindependent synapses formed between T cells and dendritic cells. Nat Immunol. 2001;2:925-31.

47. Hochweller K, Wabnitz GH, Samstag Y, Suffner J, Hämmerling GJ, Garbi N. Dendritic cells control $T$ cell tonic signaling required for responsiveness to foreign antigen. Proc Natl Acad Sci. 2010;107:5931-6.

48. Jolly C, Mitar I, Sattentau QJ. Adhesion molecule interactions facilitate human immunodeficiency virus type 1-induced virological synapse formation between T cells. J Virol. 2007;81:13916-21.

49. Seya T, Matsumoto M, Tsuji S, Begum NA, Nomura M, Azuma I, Hayashi A, Toyoshima K. Two receptor theory in innate immune activation: studies on the receptors for bacillus Culmet Guillen-cell wall skeleton. Arch Immunol Ther Exp (Warsz). 2001;49(Suppl 1):S13-21.

50. Groot F, van Capel TMM, Schuitemaker J, Berkhout B, de Jong EC. Differential susceptibility of naïve, central memory and effector memory $T$ cells to dendritic cell-mediated HIV-1 transmission. Retrovirology. 2006;3:52.

51. Sabado RL, Babcock E, Kavanagh DG, Tjomsland V, Walker BD, Lifson JD, Bhardwaj N, Larsson M. Pathways utilized by dendritic cells for binding, uptake, processing and presentation of antigens derived from HIV-1. Eur J Immunol. 2007;37:1752-63.

52. Sanchez-Lockhart M, Rojas AV, Fettis MM, Bauserman R, Higa TR, Miao $\mathrm{H}$, Waugh RE, Miller J. T cell receptor signaling can directly enhance the avidity of CD28 ligand binding. PLoS One. 2014;9:e89263.

53. Iglesias-Ussel M, Vandergeeten C, Marchionni L, Chomont N, Romerio F. High levels of CD2 expression identify HIV-1 latently infected resting memory $\mathrm{CD}^{+} \mathrm{T}$ cells in virally suppressed subjects. J Virol. 2013;87:9148-58

54. Cella M, Jarrossay D, Facchetti F, Alebardi O, Nakajima H, Lanzavecchia A, Colonna M. Plasmacytoid monocytes migrate to inflamed lymph nodes and produce large amounts of type I interferon. Nat Med. 1999;5:919-23.

55. Groot F, van Capel TM, Kapsenberg ML, Berkhout B, de Jong EC. Opposing roles of blood myeloid and plasmacytoid dendritic cells in HIV-1 infection of T cells: transmission facilitation versus replication inhibition. Blood. 2006;108:1957-64.

56. Dzionek A, Fuchs A, Schmidt P, Cremer S, Zysk M, Miltenyi S, Buck DW, Schmitz J. BDCA-2, BDCA-3, and BDCA-4: three markers for distinct subsets of dendritic cells in human peripheral blood. J Immunol Baltim Md. 1950;2000(165):6037-46.

57. O'Doherty U, Peng M, Gezelter S, Swiggard WJ, Betjes M, Bhardwaj N, Steinman RM. Human blood contains two subsets of dendritic cells, one immunologically mature and the other immature. Immunology. 1994;82:487-93.

58. Rappocciolo G, Piazza P, Fuller CL, Reinhart TA, Watkins SC, Rowe DT, Jais M, Gupta P, Rinaldo CR. DC-SIGN on B lymphocytes is required for transmission of HIV-1 to T lymphocytes. PLoS Pathog. 2006;2:e70.

59. Porichis F, Kaufmann DE. Role of PD-1 in HIV pathogenesis and as target for therapy. Curr HIV/AIDS Rep. 2012;9:81-90.

60. Chomont N, El-Far M, Ancuta P, Trautmann L, Procopio FA, Yassine-Diab B, Boucher G, Boulassel MR, Ghattas G, Brenchley JM, Schacker TW, Hill BJ, Douek DC, Routy JP, Haddad EK, Sekaly RP. HIV reservoir size and persistence are driven by $T$ cell survival and homeostatic proliferation. Nat Med. 2009; 15:893-900

61. Parry RV, Chemnitz JM, Frauwirth KA, Lanfranco AR, Braunstein I, Kobayashi SV, Linsley PS, Thompson CB, Riley JL. CTLA-4 and PD-1 receptors inhibit T-cell activation by distinct mechanisms. Mol Cell Biol. 2005;25:9543-53. 
62. Whitney G, Wang S, Chang H, Cheng KY, Lu P, Zhou XD, Yang WP, McKinnon $M$, Longphre $M$. A new siglec family member, siglec-10, is expressed in cells of the immune system and has signaling properties similar to CD33. Eur J Biochem FEBS. 2001;268:6083-96.

63. Avril T, Floyd H, Lopez F, Vivier E, Crocker PR. The membrane-proximal immunoreceptor tyrosine-based inhibitory motif is critical for the inhibitory signaling mediated by Siglecs-7 and -9, CD33-related Siglecs expressed on human monocytes and NK cells. J Immunol Baltim Md. 1950;2004(173):6841-9.

64. Ikehara Y, Ikehara SK, Paulson JC. Negative regulation of T cell receptor signaling by Siglec-7 (p70/AIRM) and Siglec-9. J Biol Chem. 2004;279:43117-25.

65. Bibollet-Ruche F, McKinney BA, Duverger A, Wagner FH, Ansari AA, Kutsch O. The quality of chimpanzee T-cell activation and simian immunodeficiency virus/human immunodeficiency virus susceptibility achieved via antibody-mediated T-cell receptor/CD3 stimulation is a function of the anti-CD3 antibody isotype. J Virol. 2008;82:10271-8.

66. Nguyen DH, Hurtado-Ziola N, Gagneux P, Varki A. Loss of Siglec expression on T lymphocytes during human evolution. Proc Natl Acad Sci. 2006;103:7765-70.

67. Soto PC, Karris MY, Spina CA, Richman DD, Varki A. Cell-intrinsic mechanism involving Siglec-5 associated with divergent outcomes of HIV-1 infection in human and chimpanzee CD4 T cells. J Mol Med Berl Ger. 2013;91:261-70

68. Chen G-Y, Tang J, Zheng P, Liu Y. CD24 and Siglec-10 selectively repress tissue damage-induced immune responses. Science. 2009;323:1722-5.

69. Bandala-Sanchez E, Zhang Y, Reinwald S, Dromey JA, Lee B-H, Qian J, Böhmer RM, Harrison LC. T cell regulation mediated by interaction of soluble CD52 with the inhibitory receptor Siglec-10. Nat Immunol. 2013;14:741-8.

70. Grosse J, Meier K, Bauer TJ, Eilles C, Grimm D. Cell separation by countercurrent centrifugal elutriation: recent developments. Prep Biochem Biotechnol. 2012;42:217-33.
71. Reed $\sqcup$, Muench $H$. A simple method of estimating fifty per cent endpoints. Am J Epidemiol. 1938;27:493-7.

72. Kim D, Pertea G, Trapnell C, Pimentel H, Kelley R, Salzberg SL. TopHat2: accurate alignment of transcriptomes in the presence of insertions, deletions and gene fusions. Genome Biol. 2013;14:R36.

73. Langmead B, Trapnell C, Pop M, Salzberg SL. Ultrafast and memoryefficient alignment of short DNA sequences to the human genome. Genome Biol. 2009;10:R25.

74. Anders S, Pyl PT, Huber W. HTSeq-a Python framework to work with highthroughput sequencing data. Bioinforma Oxf Engl. 2015;31:166-9.

75. Law CW, Chen Y, Shi W, Smyth GK. voom: precision weights unlock linear model analysis tools for RNA-seq read counts. Genome Biol. 2014;15:R29.

76. Victorian bioinformatics consortium [Internet]. Monash University, Australia, 2014b. [Available from: http://victorian-bioinformatics-consortium. github.io/degust/]. Accessed August 2014.

77. Dynamic Venn diagrams for Differential Gene Expression [Internet]. Dyn. Venn Diagr. Differ. Gene Expr. Monash University, Australia, 2014a. [Available from: http://drpowell.github.io/vennt/]. Accessed August 2014.

78. Harman AN, Wilkinson J, Bye CR, Bosnjak L, Stern JL, Nicholle M, Lai J, Cunningham AL. HIV induces maturation of monocyte-derived dendritic cells and Langerhans cells. J Immunol. 2006;177:7103-13.

79. Harman AN, Kraus M, Bye CR, Byth K, Turville SG, Tang O, Mercier SK, Nasr N, Stern JL, Slobedman B, Driessen C, Cunningham AL. HIV-1infected dendritic cells show 2 phases of gene expression changes, with lysosomal enzyme activity decreased during the second phase. Blood. 2009;114:85-94.

80. DAVID Bioinformatics resources 6.7 [Internet]. Database Annot. Vis. Integr. Discov., National Institute of Allergy and Infectious Diseases (NIAID), NIH, USA, 2015. [Available from: http://david.abcc.ncifcrf.gov]. Accessed in August 2014

\section{Submit your next manuscript to BioMed Central and take full advantage of:}

- Convenient online submission

- Thorough peer review

- No space constraints or color figure charges

- Immediate publication on acceptance

- Inclusion in PubMed, CAS, Scopus and Google Scholar

- Research which is freely available for redistribution

Submit your manuscript at

www.biomedcentral.com/submit

C BioMed Central 